\title{
İçme Suyu Havzalarının Ekosistem Yaklaşımlı Planlama Paradigmalarının Kapsamı
}

\author{
Füsun Günay ULUGERGERLi 1
}

\section{Öz}

Küresel olarak nüfus artışı ve suya olan talep arttıkça, sınırlı olan su kaynaklarının özellikle içme suyu kaynaklarının etkin ve sürdürülebilir şekilde yönetilmesi kritik önem taşımaktadır. Sürdürülebilir su kaynakları yönetimi için, suların nerede olduğu, hangi nicelik ve kalitede bulunduğu, ne kadar değişken olduğu ve gelecekte nasıl gelişeceklerinin öngörülebilmesi gereklidir. Nüfus artışı ve iklim değişikliği toplumların ve kaynakların sel ve kuraklık gibi aşırı hidrolojik olaylara maruz kalma oranını arttırırken, olayların can kayıpları ve ekonomiler üzerindeki etkisini en aza indirmeye yardımcı olabilecek erken uyarı bilgileri ve ürünleri sunmakta çok önemli hale gelmiştir. Kısıtlı doğal kaynaklardan olan su kaynakları değerlendirilirken tehlikeler ve tehditlere göre planlamalar yapılması, işletilmesi ve sürekliliğinin sağlanmasında, doğal ekosistemler dikkate alınarak havza bazında çalışmak önemli katkı sunmaktadır. Kapsamlı havza yönetimi multidisipliner veri gerektirmektedir. Toplumlar için çeşitli ekosistem servislerinin sürdürebilirliğinde havza yönetiminin kullanılması önemli araştırma alanıdır. Sağııkı ekosistemler hem insan toplulukları hem de ekosistem servisleri için karşılıklı fayda sağlamaktadır. Havza seviyelerinin sağlıklı ekosistem açısından yeterli olmaması, gelecek nesillerin sağlayacağı faydaları tehlikeye atabilir. Bu nedenle tüm ekolojik planlama süreçleri dikkate alınarak havza çalışmaları yapılmalıdır. Bu bağlamda stratejik doğal kaynaklardan olan suyun sürdürülebilir kullanımı, su sistemlerinin ve bunlara bağlı ekosistemlerin havza bazında korunması, iyileştirilmesi ve olası tahribatların önlenmesi için yapılan çalışmaları kapsamaktadır. Bu çalışma hem mevcut su havzalarının yönetilmesi hem de gelecekte intiyaç duyulacak miktarlar için su havzalarının planlanmasında, ekosistem yaklaşımlı yapılan çalışmaların sunduğu katkılar üzerine yoğunlaşmaktadır.

Anahtar Kelimeler: İçme suyu havzası, Havza yönetimi, Ekosistem servisleri, Bütünleşik havza yönetimi.

\section{The Scope of Ecosystem Approach Planning Paradigm of Drinking Water Basins}

\begin{abstract}
Due to the global rising of population and water demand, effective and sustainable management of limited water resources especially drinking water usage is critical. Therefore it is necessary to be able to predict where the waters are, in what quantity and quality, how variable they are, and how they will develop in the future. Exposure of communities and resources to extreme hydrological events such as floods and droughts increase driven by population growth and climate change, has become very important to provide early warning information and products that can help minimize the impact of events on the loss of life and

\footnotetext{
1 Jeoloji Mühendisliği, Lisansüstü Eğitim Enstitüsü, İstanbul Teknik Üniversitesi, İstanbul, Türkiye *Ilgili yazar/Corresponding author: fusun.ulugergerli@gmail.com

Gönderim Tarihi / Received Date: 08.02.2021
}

Kabul Tarihi / Accepted Date: 01.11.2021


economies. While evaluated water resources which are limited natural resources make the planned use of natural ecosystems with dangers and threats and ensuring their continuity, makes it significant to work on the basin. Comprehensive watershed management requires multidisciplinary data. The use of watershed management in the sustainability of various ecosystem services for communities is an important research area. Healthy ecosystems are provided mutual benefits for both communities and ecosystem services. If the basin levels are not sufficient for a healthy ecosystem, the benefits of future generations can be jeopardized. Therefore, basin studies should be carried out taking into account all ecological procesess. This context includes the sustainable use of water which is one of the strategic natural resources, the protection, and improvement of water systems and related ecosystems on a basin, and the studies carried out for preventing possible damages. This study focuses on both topics that existing water basin management and planning of the number of water basins will be needed in the future and contributes to the ecosystem approach planning.

Keywords: Drinking water basin, Watershed management, Ecosystem services, Integrated watershed management

\section{Giriş}

Birçok bilim insanı dünyanın yüz yüze geldiği en büyük çevre sorununun aşırı nüfus olduğunu düşünmektedir. Bu insanların beslenmek, barınmak, giyinmek ve tüm bunları çevrede en az etki bırakacak şekilde yapmak zorunda olduğunu unutulmamak gerekir. Artan nüfus için güvenilir ve yeterli su kaynakları bulunmalı ve kirlikten uzak tutulmalıdır (Monroe ve Wicander, 2005:9-10). Dünyadaki tatlı su oranı azdır. Dünyadaki tüm suların yalnızca \% 2.5 içilebilir su olarak kullanılabilir. Bunun da ancak \%1' i ne erişme imkanı bulunmaktadır (URL-2). Birleşmiş Milletler Dünya Su Raporu (2019)'na göre dünya üzerinde 2.1 milyar insanın temiz suya düzenli erişimi bulunmamaktadır (URL-3). Oysa, içilebilir su kaynaklarına erişim, temel haklardan biridir ve toplumların gelişmesine katkıda bulunmaktadır. Fakat dünya nüfusunun üçte biri güvenilir şekilde içme suyu hizmeti alamamaktadır (URL-4). Ek olarak dünya nüfusu için güvenli olmayan su önde gelen ölüm risk faktörlerinden birini oluşturmaktadır (URL-5). Konuya ilişkin rakamlar ile bu durum özetlenir ise: Her yıl 1.2 milyon insanın ölümünden güvenli olmayan su sorumludur. Gelir seviyesi düşük ülkelerde güvenli olmayan su kaynakları sonucu ölüm oranı \%6'dır. 666 milyon insanın (dünya nüfusunun \%9) su kaynaklarına erişimi bulunmamaktadır. 2.1 milyar insanın (dünya nüfusunun \%29) güvenli içme suyuna erişimi bulunmamaktadır (Şekil 1) ( URL-7).

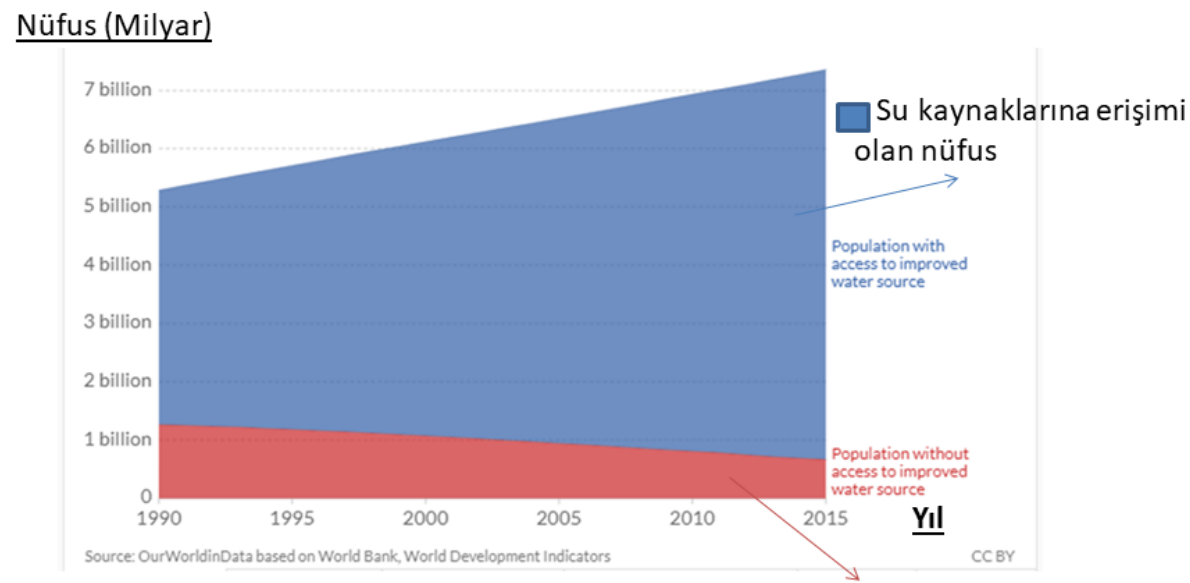

Su kaynaklarına erişimi olmayan nüfus

Şekil 1: Güvenli suya erişen ve erişemeyen insan sayısı 1990-2015 (URL-7) 
Dünya Sağlık Örgütü verilerine göre suları arıtarak güvenli su haline getirmenin maliyeti, güvenli olmayan su kullanımından kaynaklanan sağlık sorunlarının maliyetinden daha düşüktür (Kentli Dergisi, 2018:48). Sürdürülebilir gelişmede temel haklardan olan içilebilir suya erişim konusu çok yönlü planlamalar gerektirmektedir. Olayın fiziksel ve çevre boyutları, sosyal boyutu, yasal ve politik boyutları, ekonomik boyutu gözetilerek planlamalar yapılması önemlidir.

Dünyamızda son yıllarda hızla artan nüfus ile beraber sanayileşme, tarımsal faaliyetler ve diğer sektörlerin su taleplerinde yaşanan artış ve iklim değişikliğinin etkileri su kaynakları üzerinde kalite ve miktar açısından ciddi baskılar oluşturmaktadır. Illaveten, sürdürülebilir olmayan su yönetimi ve uygulamaları doğal hidrolojik döngülerin kırılmasına sebep olmaktadır. Bunun birlikte su kaynakları birbiriyle bağlı birçok doğal kaynaktan beslenmekte ve antroponejik kökenli girişimlerin varlığı sebebi ile yapı itibari ile dinamik ve değişken özellikler göstermektedir. Bu sebeplerle su kaynaklarının özel olarak yönetilmesi ve durumlarının her aşaması gerekli izlemelerle takip edilerek potansiyel tehlikelerin su kaynaklarına etki etmeden saptanması ve önlenmesi gerekmekte, ekolojik ve kimyasal durumunun bütüncül bir yaklaşımla havza bazında korunması ve iyileştirilmesi önem arz etmektedir (Selek ve Karaaslan, 2019:1). Günümüzde büyüyen ve nüfusu artan yerleşim alanlarına nitelik ve niceliği daha yüksek su sağlamak önemli sorun olmaktadır. Yanlış arazi kullanımı ve özellikle yukarı havzada yapılan yanlış uygulamalar su kaynaklarının azalmasında önemli faktörleri oluşturmaktadır. İstenilen kalite ve miktarda su üretmenin yolu suyun doğal ekosistemi içinde depolanması ve buradan tüketim alanlarına iletilmesidir. Bu bağlamda planlamalar havza bazında yürütülmeli ve ekosistem anlayışı tüm sektörlere benimsetilmelidir (Göl, 2008:175176). Suyun korunması ve sürdürülebilir kullanımının ekosistem bütünlüğünde planlamalarının yapılması için "havza" en elverişli birim ve ölçek kabul edilmektedir (Kentli Dergisi, 2018:63).

Havza yönetimi havza sınırları içinde, su ve diğer doğal kaynakların koruma-kullanma dengesini gözeten, ekolojik ve ekonomik kaygılarla, yeni teknolojileri de dikkate alarak stratejik plan ve programların üretildiği bir doğal kaynak yönetimidir. Ayrıca havza yönetimi ekolojik planlama ilkeleri ile ekosistemlerin sınılarını pratikte alansal yönetim uygulamalarına dönüştüren hem doğal kaynak hem de mekansal planlama aracı olarak sosyo-kültürel ve ekonomik kalkınmanın bütünleşik olarak planlanması ve yönetilmesi uygulamalarıdır. Ekosistem yaklaşımına dayalı havza yönetiminde ise, bütüncül havza yönetimi ile uyumlu ve ekosistemlerin sunduğu çok yönlü fayda ve ürünleri daha rasyonel değerlendiren bir içerik söz konusudur (Kentli Dergisi, 2018:60).

Ekosistem içerisinde birbiriyle çelişiyormuş gibi görünen sosyo-ekonomik ve çevresel amaçlar ile arazi kullanımının, yüzey suları ve diğer çevresel değerler üzerinde olan olumsuz etkisini minimize ederek ihtiyaçları karşılayacak bir kalkınma anlayışı arasındaki dengeyi kurma çabası olduğu önemlidir (Göl, 2008:175-176).

Ancak kapsamlı havza yönetimi zor bir iştir ve multidisipliner bilgi gerektirmektedir. Geleneksel havza yönetim modelleri, sistem heterojenliğini yakalamada etkin olmayıp, insan ve doğal sistemler arasındaki iki yönlü etkileşimi sınırlandırmaktadır. Su kaynakları sistemlerinin geleneksel modelleri, tek bir hedef kullanarak su kullanıcıları ve kullanım alanları arasındaki heterojenliği görmezden gelmektedir Oysa tüm ekolojik işlevler dikkate alınarak havza çalışmaları yapılmalıdır. Sürdürülebilir havza yönetimi, su sistemleri ve onların doğal çevre ile etkileşimlerini anlamayı gerektirmektedir (Khan vd., 2017 :6275-6276).

Sonuç olarak bu çalışmada içme suyu havzalarının sürdürülebilir yönetimine ekosistem anlayışının sunduğu katkılar üzerine yapılan literatür taramalarının yorumlanması ile havzaların ekolojik işlevleri bağlamında daha kapsamlı sonuçlar sunabileceği irdelenecektir. 


\section{Araştırmanın Amacı ve Veri Toplama Yöntemi}

Araştırmanın amacını " "içme suyu havzalarının ekosistem yaklaşımlı planlama paradigmaların kapsamı" konusunu incelemek oluşturmaktadır. Bu amaç ile literatür taraması yapılmış, konu ile ilgili makale, tez ve eğitim notlarından yararlanılmıştır.

Bu araştırmada kullanılan verilerin büyük kısmı, 2020 yılı hariç tutularak Mayıs 2020 tarihinde Scopus veri tabanından elde edilmiştir. Bu veri tabanı seçilmesi üzerindeki en büyük etken konu ile ilgili seçilen anahtar kelimeler aracılığı ile yayınlanmış yayınların rahat derlenebildiği, kabul gören veri tabanı olmasıdır. Arama yöntemi, konu başlığı ile alakalı anahtar kelimeler ile gerçekleştirilmiştir. Anahtar kelimeler olarak ilk önce " Havza Yönetimi" ve "Ekosistem Servisleri" seçilmiş, sonra da "Bütünleşik Havza Yönetimi" ve "Ekosistem Servisleri" olarak yapılmıştır. Zaman aralığı 2020 yılı hariç tutularak yapılan ilk taramadan sonra, erişime açık tüm yayınlara ulaşılmaya çalışılmıştır. Aynı aramanın zaman kısıtı olmadan yapııması durumunda ise farklı sonuçlara ulaşılması normaldir.

- Arama sonucunda ulaşılan yayınların açıklaması Literatür İncelemesi kısmında verilmektedir.

- Bu çalışma da İçme Suyu Havzaları ve Ekosistem Servisleri konulu yayınlarda terimler arasında ki ilişkiyi analiz etmek ve görselleştirmek için VOSviewer yazılımı kullanılmıştır.

Görselleştirmelerin yorumu, Literatür İncelemesi bölümünde, bulgular kısmında açıklanmıştır. Çalışmada yazar, atıf (Citation), bibliyografik eşleştirme (Bibliographic-Coupling), ortak atıf analizi (Co-citation Analysis) uygulamaları yapılmamış, yalnızca 2020 yılı yayınları tarama harici tutulmuştur.

Sonuç olarak "İçme suyu havzalarının ekosistem yaklaşımlı planlama paradigmaları" konulu araştırma da Scopus veritabanı üzerinde anahtar kelimeler ile yapılan araştırmalar ile ayrıca ulusal ve uluslararası kurumların web sayfalarında yapılan araştırmalar ve çıktıları kullanılarak ve kullanılan modeller incelenerek, bunlar üzerinden yorum yapılmıştır.

\section{Literatür İncelemesi}

\subsection{Bulgular}

Bu bölümde Scopus analiz sonuçlarından elde edilen bulgulara yer verilmiştir.

Konu ile ilgili olarak "Havza yönetimi" ve "Ekosistem servisleri" anahtar kelimeleri ile Scopus veri tabanında yapılan araştırmada 2020 yılı kısıtlaması ile 172 adet yayına ulaşılmıştır. Bu yayınların 41 tanesi erişime açıktır. Bu yayınlar 1999 ile 2019 yılları arasında yayınlanmış olup, özellikle son yıllarda yapılan yayın sayısında 2010 yılı itibari ile artış tespit edilmiştir. Toplam 172 yayının 149 tanesi son 10 yıl a ait olup yıl bazında analizi Şekil 2 'de, yayınların hangi alanlarda yapıldığının analizi Şekil 3'de görülmektedir. Şekil 2'de görüldüğü üzere en fazla çalışma 20 adet ile 2012 yılında yayınlanmış, bunu 19 adet ile 2019, 18 adet ile 2018 yılları izlerken, 2000 ve 2003 yıllarında ise hiç yayın bulunmamaktadır. 


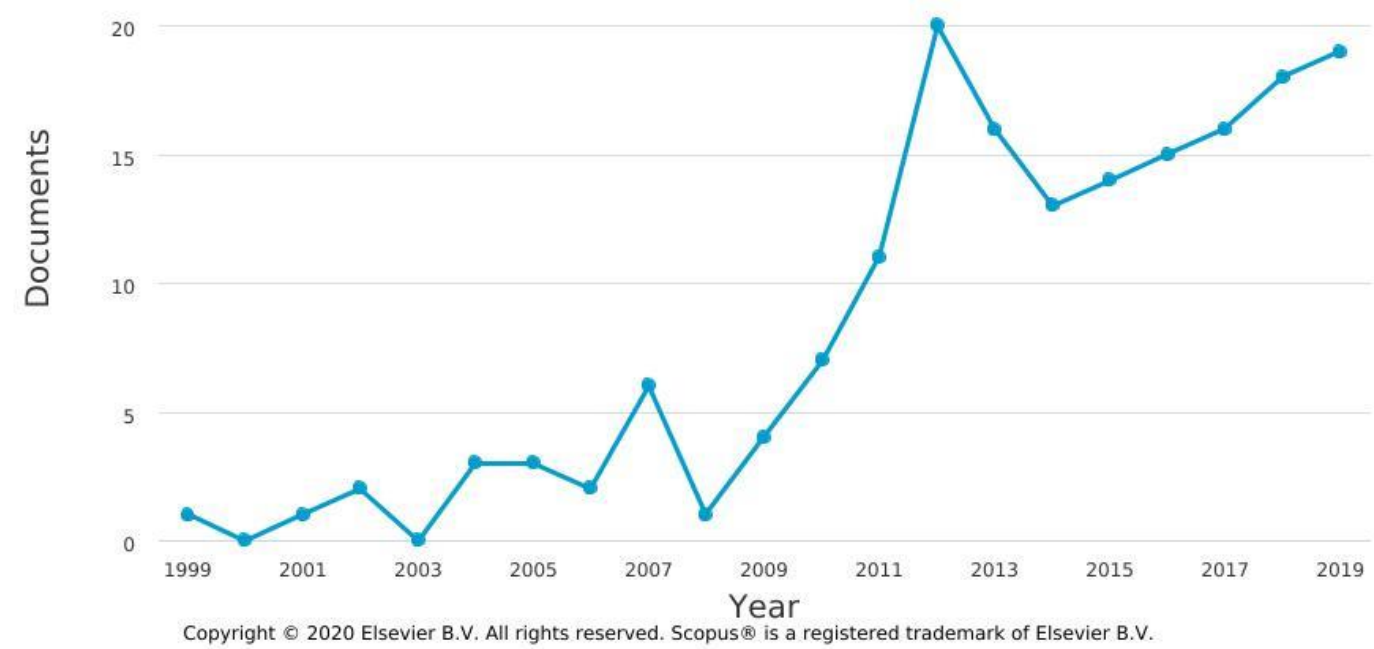

Şekil 2 : "Watershed Management" and "Ecosystem Services" anahtar kelimeleri ile yapılan yayınların yıllara göre sayısı

\section{Documents by subject area}

\section{Scopus}

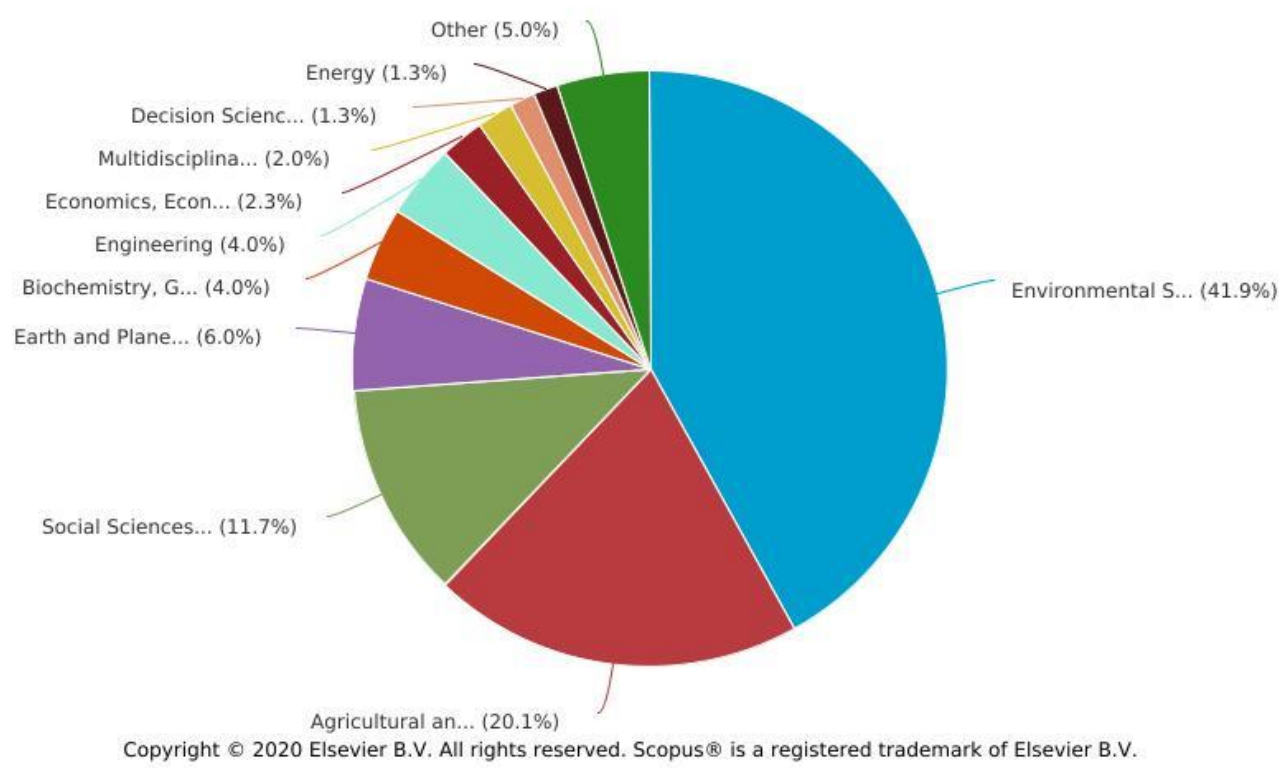

Şekil 3 : "Watershed Management" and "Ecosystem Services" anahtar kelimeli yayınlarının sektörel dağılımı

En fazla yayın sırası ile 125 adet (41.93\%) Çevre Bilimleri, 60 adet $(20.1 \%)$ Tarım ve Biyoloji, 35 adet $(11.7 \%)$ Sosyal Bilimler alanlarında, en az sayıda yayın ise 4'er adet (1.3\%) ile Karar Bilimi ve Enerji alanlarında yapılmıştır (Şekil 3). Konunun en fazla Çevre Bilimleri ile Tarım ve Biyoloji alanlarında ele alınması, canlı yaşamının devamı için gerekli olan su havzaları ile tarım, gıda ve beslenme kaynakları varlığının, devamlılığının ekosistemler ile ne kadar iç içe ve hassas konular olduğunu ön plana çıkarmaktadır. 


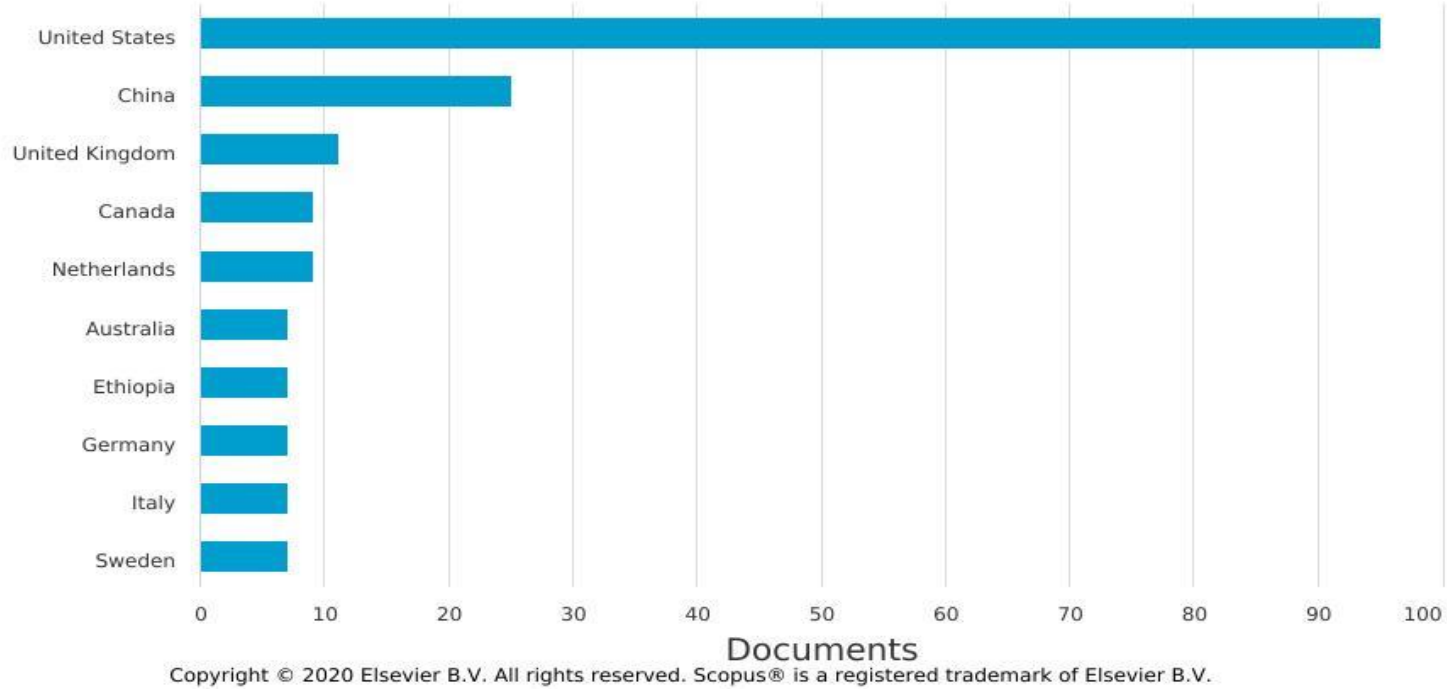

Şekil 4: "Watershed Management" and "Ecosystem Services" anahtar kelimeleri ile ülkelere göre yayın sayıları

Ülkeye göre yayın sayılarına bakıldığında, Havza Yönetimi ve Ekosistem Servisleri kavramlarına yayınları ile katkı yapan ilk iki ülke USA ve Çin (Şekil 4). Bu analize göre en fazla yayının USA ve Çin' de yapılmış olması, sahip olunan doğal su kaynaklarının sürdürülebilirliğine artan nüfus ve endüstriyel bağlamında yoğunlaşıldığının göstergesidir. Yayın sayıları en çok, tüketim ve üretimin fazla olan ülkeler tarafından gerçekleştirilmektedir.

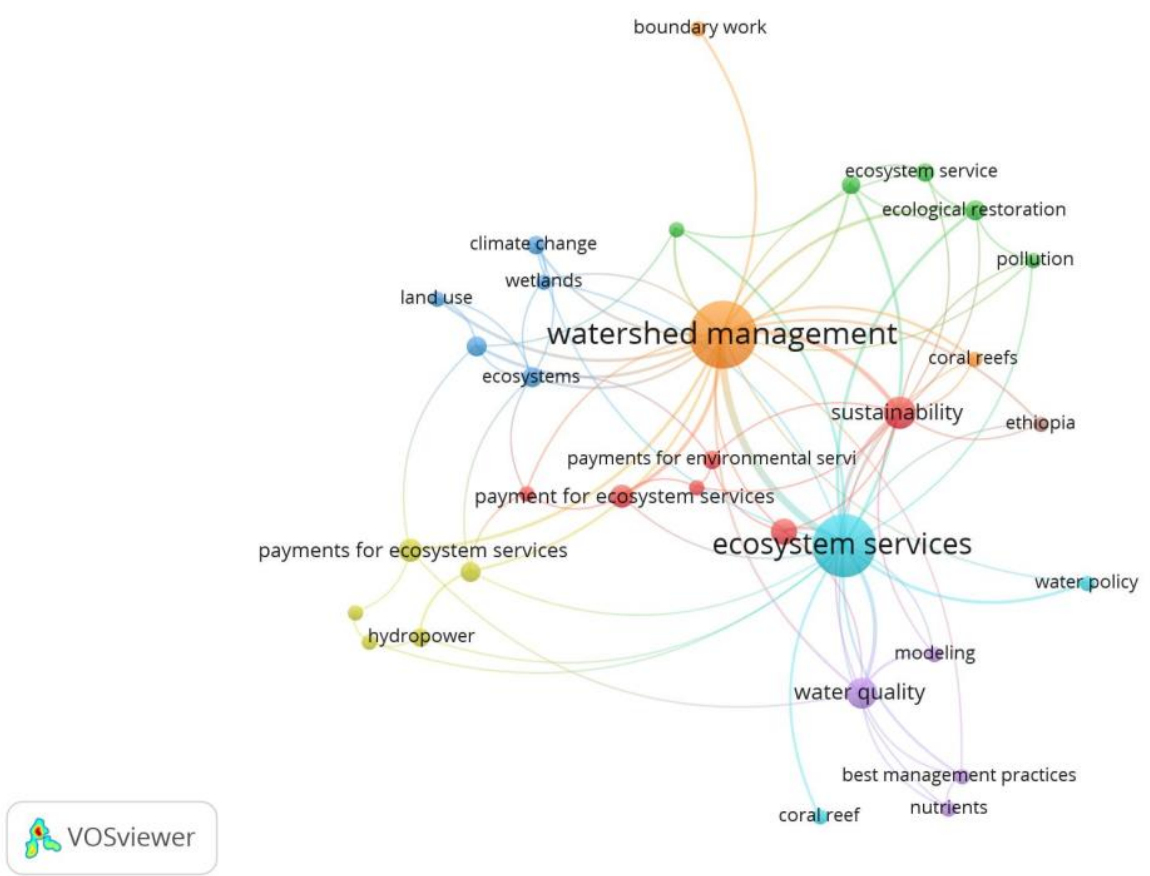

Şekil 5: Konu kategorisinde kelimeler arasındaki ağ görseli

Havza Yönetimi ve Ekosistem Servisleri konusuna katkıda bulunan ve birbiri ile korelasyon eğilimi gösteren konular Şekil 5'de, yoğunluk görseli ise Şekil 6'da gösterilmektedir. 


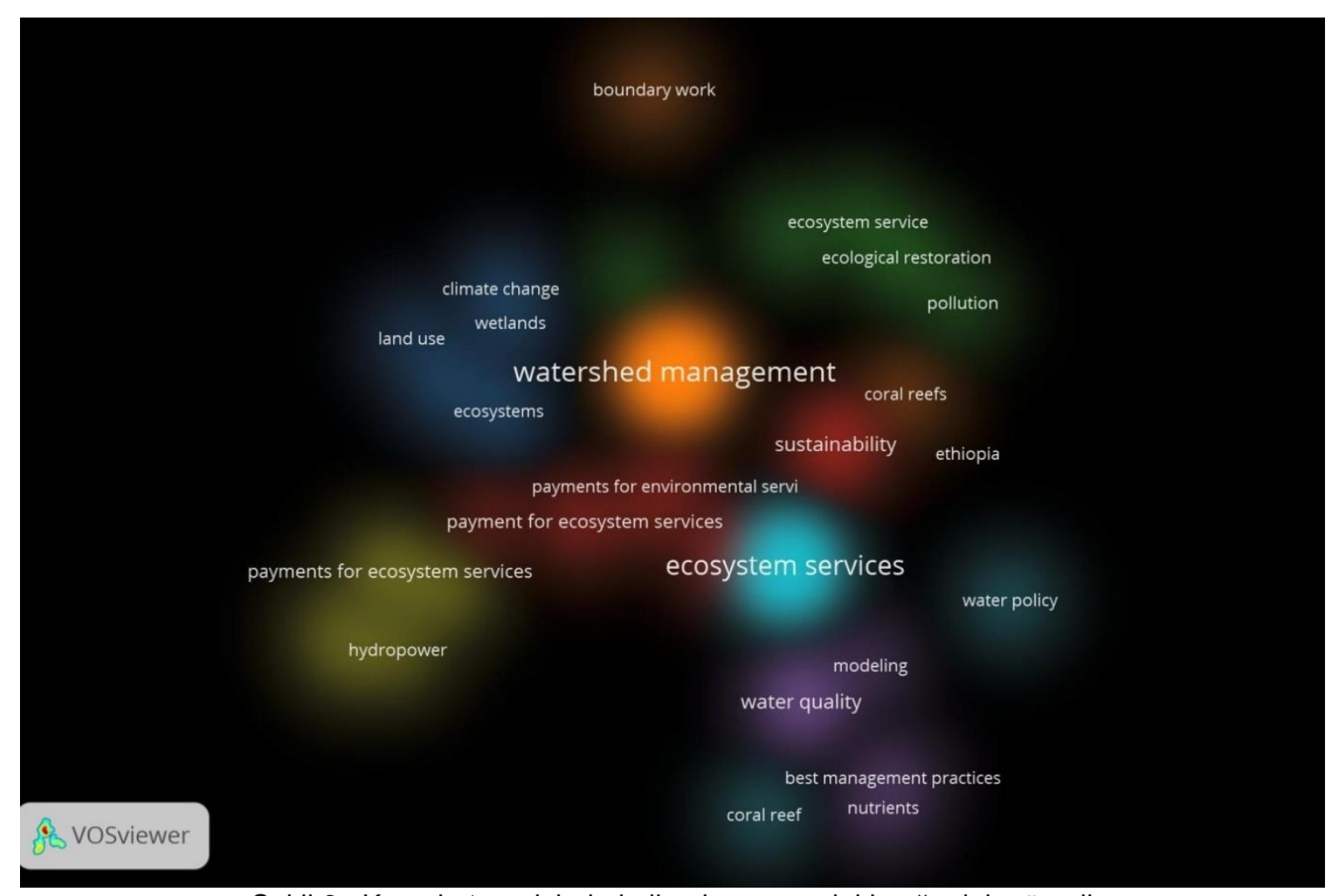

Şekil 6 : Konu kategorisinde kelimeler arasındaki yoğunluk görseli

Görselden de (Şekil 6) anlaşılacağı üzere bağlantı gücü ve yoğunluğu en yüksek kelimeler ekosistem servisleri, su yönetimi üzerinedir.

Konu ile ilgili seçilen anahtar kelimeler "Bütünleşik havza yönetimi" ve "ekosistem servisleri" ile Scopus veri tabanında arama yapıldığında 18 adet yayına ulaşılmaktadır ve bunlardan 1 tanesi erişime açıktır. İlk yayın 2004 yılında Güney Afrika'da tarımı iyileştirmek için su kaynaklarını güvence altına alma amacı ile bütünleşik havza yaklaşımı ve ekosistem fonksiyonları üzerine yapılan araştırmadır. Erişime açık olan tek yayın ise 2016 yılında yapılan "Yukarı Mississipi havzasında farklı ekosistem servislerinin için sağlanan tatlı suyun değerlendirilmesi” başlıklı çalışmadır.

Havza yönetimi ve ekosistem servisleri anahtar kelimelerine göre 172 adet olan yayın sayısının, bütünleşik havza yönetimi ve ekosistem servisleri ile tarama yapıldığında 18 adete düşmüş olması dikkat çekicidir. Konunun bütüncül olarak ele alınması ne yazık ki az sayıda yayınla desteklenmektedir. 


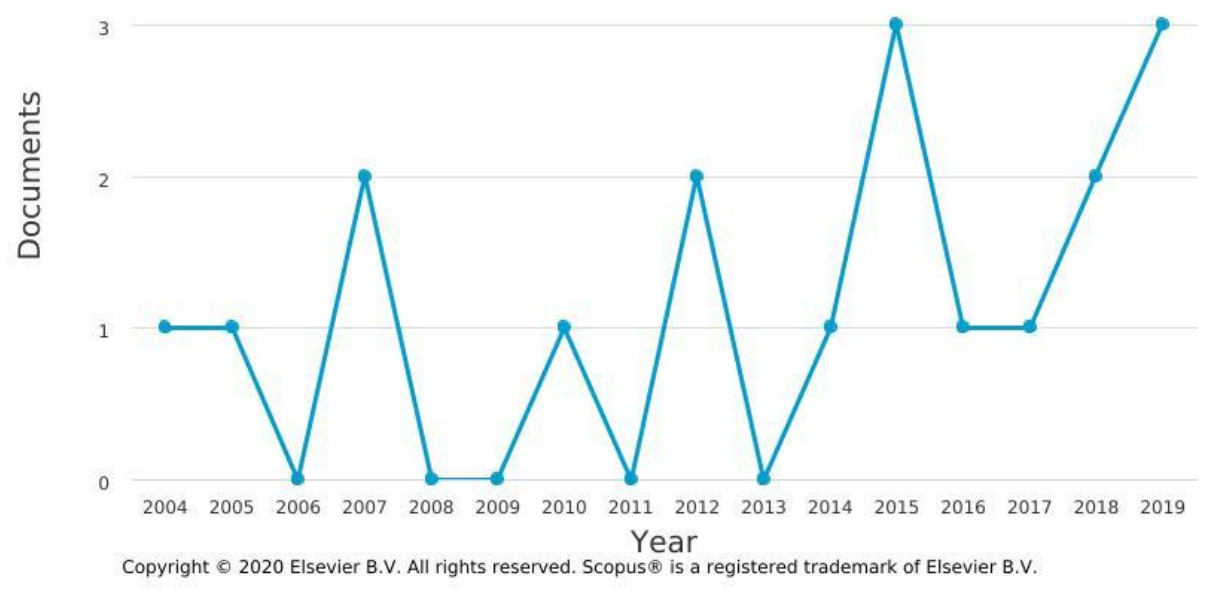

Şekil 7 : "Integrated Watershed Management" and "Ecosystem Services"anahtar kelimeleri ile yapılan yayınların yıllara göre sayısı

Grafik analizde (Şekil 7) , 2004 ile 2019 yılları arasında yayın sayısı18 adet olup, 2008, 2011, 2013 yıllarında ise yayın yapılmadığı görülmektedir.

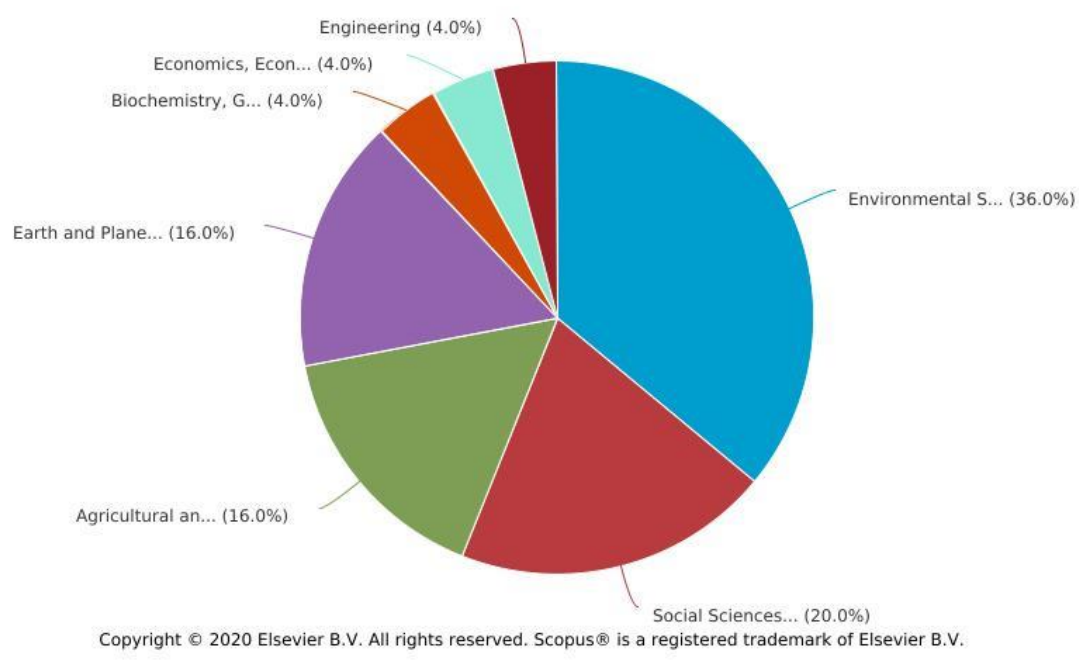

Şekil 8 : "Integrated Watershed Management" and "Ecosystem Services" anahtar kelimeli yayınların sektörel dağılımı

Konu ile ilgili en fazla yayın 9 adet (36 \%) Çevre Bilimleri, 5 adet yayın (20\%) Sosyal Bilimler,4 adet yayın (16\%) Tarım ve Biyoloji, 4 adet yayın (16\%) Dünya ve Gezegen Bilimi alanlarında, en az sayıda ise 1'er adet yayın (4 \%) ile Ekonomi ve Finans, Biyokimya, Genetik ve Moleküler Biyoloji ve Mühendislik alanlarında yapılmıştır (Şekil 8). Az sayıda yapılan yayınlarının özellikle Çevre Bilimleri ve Sosyal Bilimler üzerinde yoğunlaşmış olması, canlıların temel ihtiyaç olan temiz su kaynakları ile doğal ekolojik sistemler arasında sürdürülebilir denge olmasının yapılan çalışmalara yansımış hali gibi durmaktadır. 


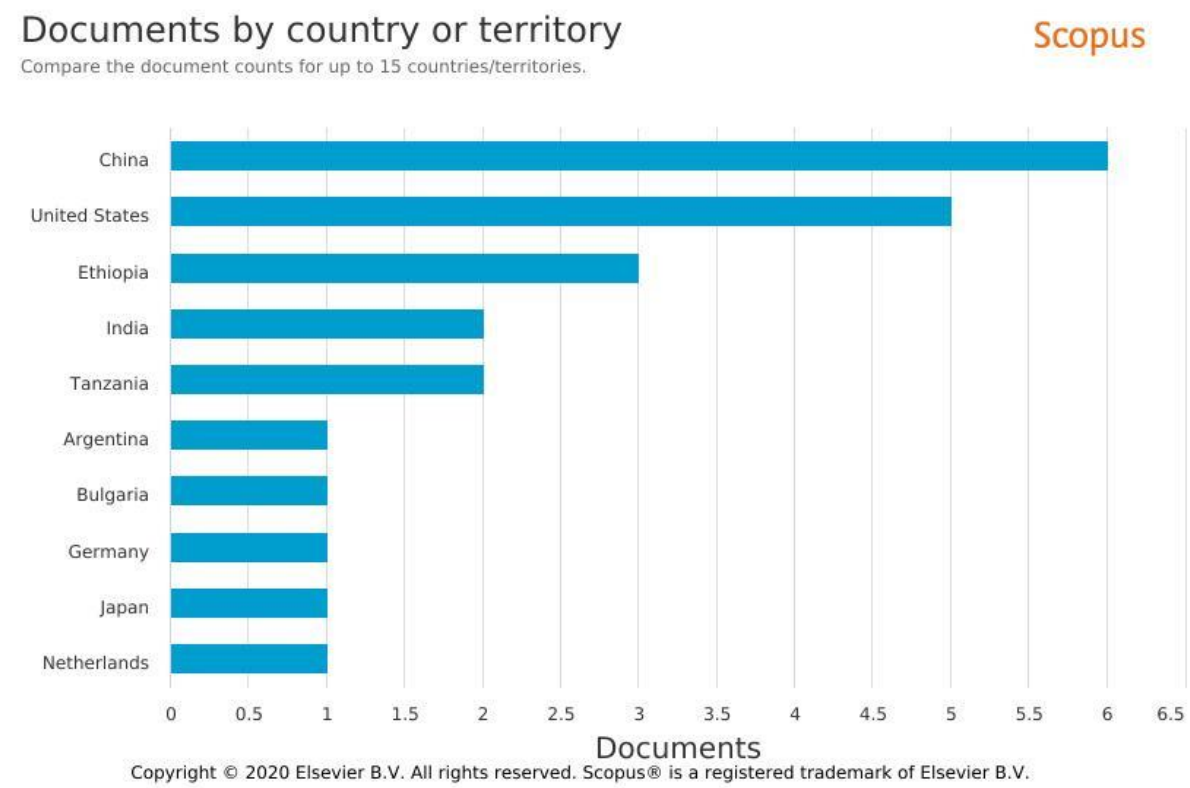

Şekil 9 : "Integrated Watershed Management" and "Ecosystem Services" anahtar kelimeleri ile yayın yapan ülkeler

Şekil 9'da konu ile ilgili ülkeye ya da bölgeye göre en fazla yayının sırası ile Çin ve USA'de yapıldığı görülmektedir. Anahtar kelimeler değiştiğinde yayın sayısı değişse dahi yayın yapan ülkelerin aynı olmasından, ülkelerin nüfusu ile temiz su intiyacı gereksiniminin yapılan çalışma sayısına yansıdığı sonucu çıkarılabilir.

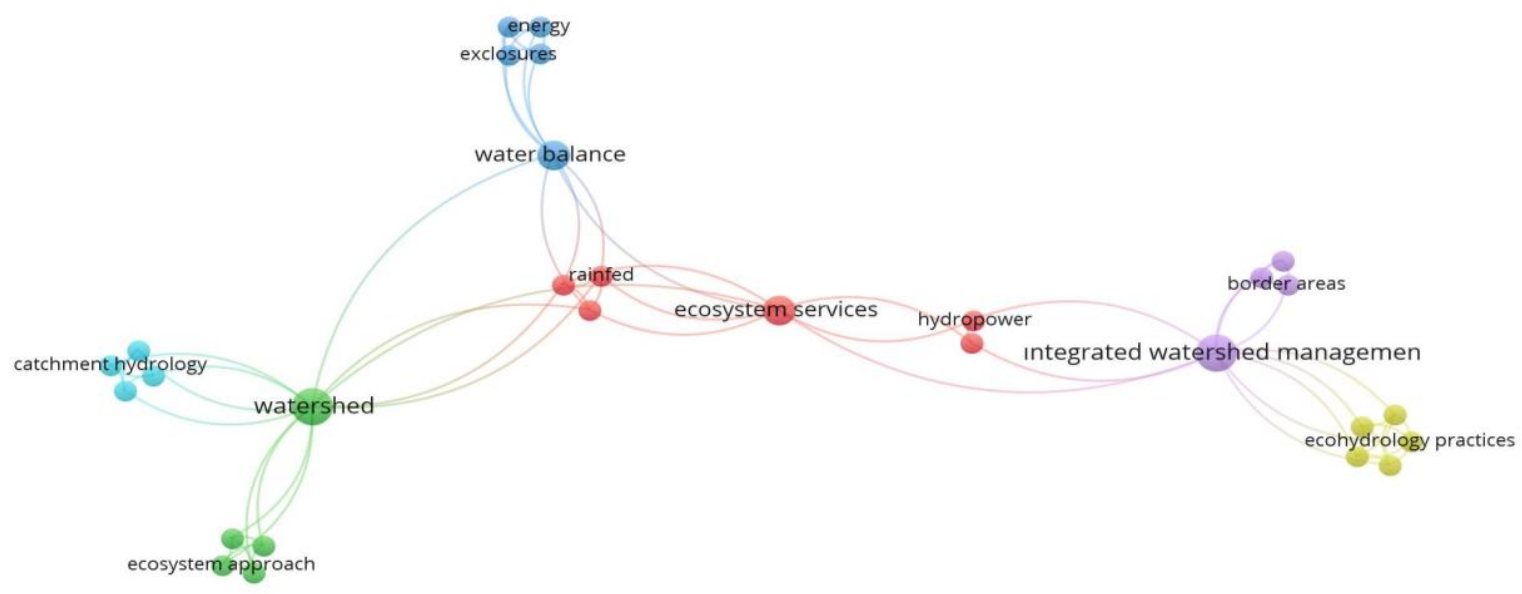

\section{fis vosviewer}

Şekil 10 : Konu kategorisinde kelimeler arasındaki bağın görüntülenmesi

Anahtar kelimeler olan bütünleşik havza yönetimi ve ekosistem servisleri terimlerin diğer terimlerle VOS viewer programındaki ağ görseli Şekil 10' daki gibidir. Görselden de anlaşılacağı üzere en çok kullanılan terimler; bütünleşik su havza yönetimi, havza sınırları, ekosistem servisleri, su havzası, su dengesi, ekohidroloji pratikleri. 


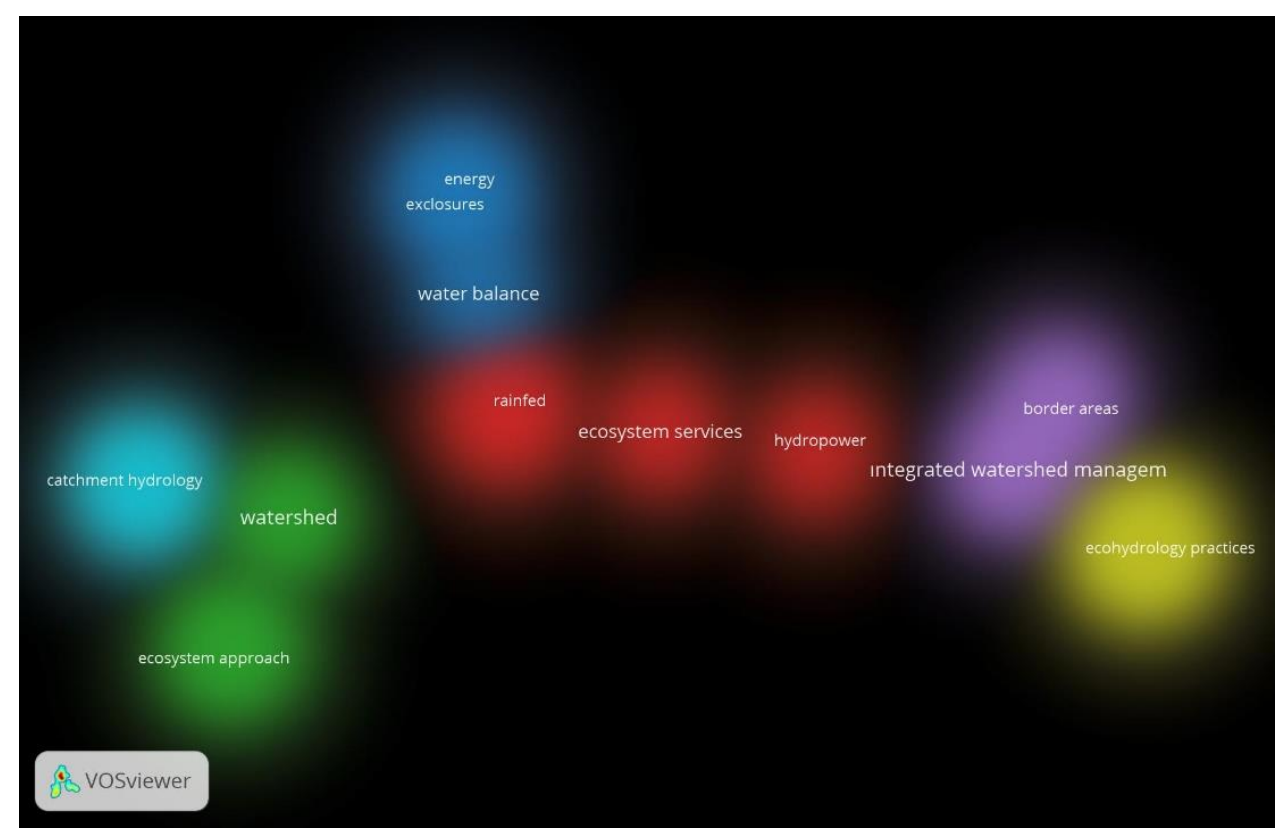

Şekil 11 : Konu kategorisi yoğunluk gösterimi

Şekil 11'de kullanılan terimler en azdan çoğa doğru mavi, buna ek olarak yeraltı sularında kirliliğin azaltılması ve daha fazla kirlenmesinin engellenmesi, taşkın ve kuraklığın etkilerinin azaltılması, sarı, mor ve kırmızı renkler ile görselleştirilmiştir. Renklendirmeden de görüldüğü üzere en fazla yoğunluğu olan kelime büyük daire mor renk ile temsil edilen bütünleşik havza yönetimi terimidir. Sayı olarak fazla olan kırmızı renkli daireler ise ekosistem servisleri terimleri konusu üzerinde yoğunlaşmaktadır.

\subsection{Erişime açık yayınların kapsamı}

Hem bütünleşik havza yönetimi ve ekosistem servisleri hem de havza yönetimi ve ekosistem servisleri anahtar kelimeleri ile Scopus veri tabanında ulaşılan erişime açık yayınlar incelendiğinde; farklı ülkeler ve farklı sektörlerde mevcut havzaların artan su, gıda, enerji talebine cevap verebilmesi ve sürdürülebilir ekosistemler için çeşitli modeller üzerinde çalışmalar yapıldığı görülmüştür. Ayrıca ES yöneten paydaşlar arasındaki roller ve güç dağılımı üzerine yapılan amprik çalışmalara da ulaşılmıştır. Bu yayınlara örnek olması amacı ile farklı alanlarda/sektörlerde ve farklı ülkelerde yapılan birkaç çalışma aşağıda verilmektedir.

"Bütünleşik havza yönetimi" ve "ekosistem servisleri" anahtar kelimeleri taramasında erişime açık tek makale Ping Li vd. tarafından yayınlanmıştır. Water dergisinde 2016 yılında yayınlanan, Yukarı Mississipi Nehri 1995-2013 yılları arası 13 havzada farklı ekosistem servisleri için tatlı su temini ile sürdürülebilir ve bütünleşik havza yönetimini geliştirmek için yapılan model çalışmaları üzerinedir. Çünkü tüm bu 13 su havzasında yıllık tatlı su sağlama endekslerinin azaldığı tespit edilmiş ve model çalışmaları ile su tedarikini etkileyen hassas faktörleri iyileştirme amaçlı çalışmalara odaklanılmıştır (Li Ping ve diğ.,2016).

Havza yönetimi ve ekosistem servisleri anahtar kelimeleri taramasında erişime açık yayınlardan biri olan Hassaan Furqan Khan vd. tarafından yapılan 2017 yılında Hydrol. Earth Syst. Sci yayınlanan nehir havzaları üzerine yapılan çalışmadır. Çalışmada genelleştirilmiş ABM (agent-based modeling) çerçevesi, iki sınır aşan nehir havzasında test edilmiştir. Nehirler; Güneydoğu Asya Mekong nehir havzası ve Batı Afrika Nijer nehir havzası. Bu havzalarda gıda, enerji kaynaklarına artan talep ile sağlıklı ekosistemler için su kullanımı arasında rekabet bulunmaktadır. Bu iki havzada bütünsel FWEE (food-water-energy-environment) yönetim politikaları ile havza genelinde hem bitki, enerji üretimi hem de ekohidrolojik indikatörler için 
modelleme sonuçları sunulmaktadır (Şekil 12). AMB raporları, $\mathrm{R}$ istatistik dili kullanılarak oluşturulur. Rapor, rezervuar ve sulanan alan ile ilişkilidir. Girdi olarak kalibre edilmiş SWAT (soil and water assessmet tool) modeli kullanılarak gelecek dönemler için Hidrolojik simulasyon yapılır. SWAT havza suyu kaynakları üzerindeki insan müdahalesinin etkilerini araştırmak için kullanılmış olan bir hidrolojik modelleme platformu olup, su havzası düzeyinde simulasyonlar yapar. SWAT taki bitkisel üretim ve rezervuar modülleri ile ABM ve hidroklimatoljik durumları, su yönetim kararlarını yönlendirmede kullanılır. SWAT modelinden elde edilen çıktı, ABM'nin girdisidir. Son sefer çalıştırılan model ABM üç su kullanımının her birinin performansını özetleyen rapor sunar; tarım, hidroelektrik ve ekoloji. ABM de ki en önemli girdi, ekosistem etkin noktalarıdır. Ekosistem etkin noktaları nehir havzasındaki belirli bölgelerdir. Bu bölgeler tüm havzadaki ekosistem sağlığının göstergesi niteliğindedir. Bu yayında hem sistem heterojenliği hem de bağlantıya etkin şekilde hitap eden insan toplulukları ve havzada ki su döngüsü - hidrolojiyi etkileyen modelleme çerçevesi çalışılmıştır. Bunun için ekosistem servislerinin paydaşları farklılaştırılarak, su kullanım tercihleri, lokasyon, havza stok ve akışının değişen çevreye göre simülasyonu gibi süreç temelli havza modellemesi yapılmıştır (H. F. Khan vd., 2017).

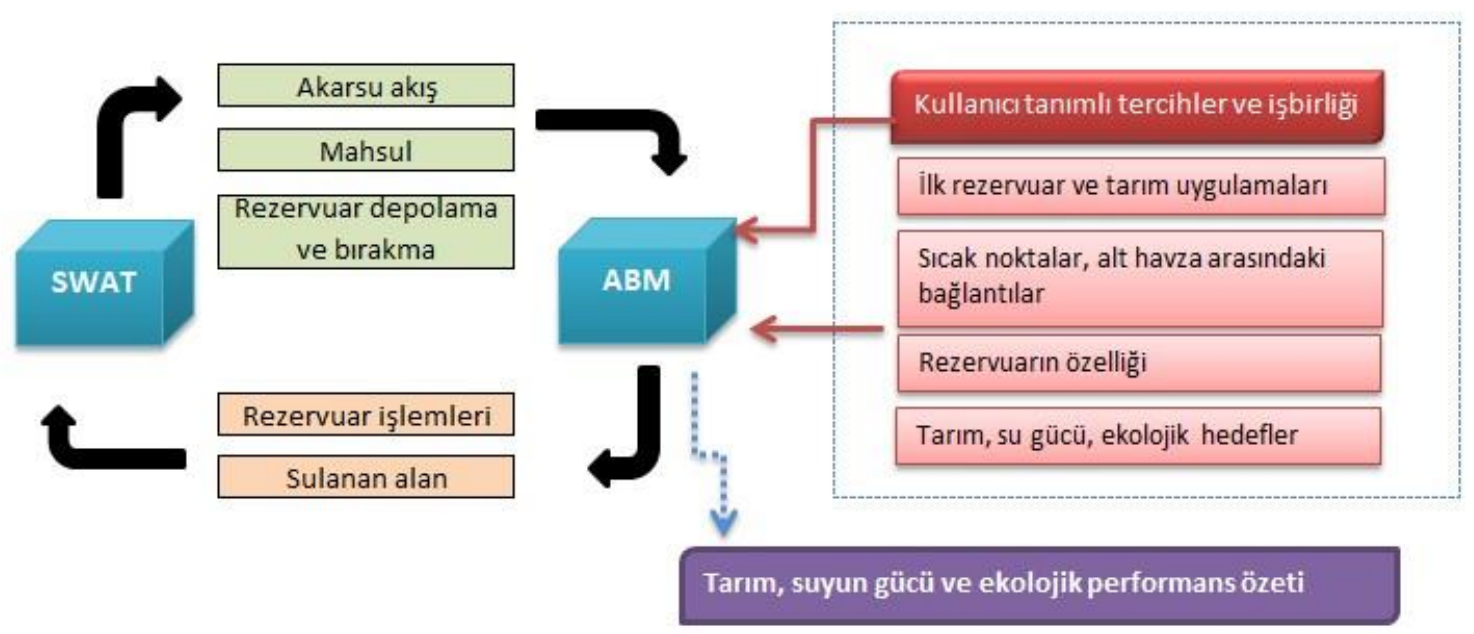

Şekil 12 : ABM ile SWAT ı birleştiren modelleme çerçevesine genel bakış (H. F. Khan vd., 2017)

2013 yılında Water'da yayınlanan Laura M. Norman ve diğ. yaptıkları çalışma, ekosistem servislerinin değişiklikleri ölçme ve değerlendirmesi ile iki ülkenin-ulusal su politika senaryolarına çerçeve oluşturması konu edilmektedir. ABD-Meksika sınırında Arizona-Sonora bölgesinde Santa Cruz Havzasında, bulunan uluslararası tesis Arizona'daki nehre deşarj edilmeden önce sınırın her iki ülke tarafındaki şehirden gelen atık suyu arıtmaktadır. Bu yazıda, modelleme ve görselleştirme ile nadir karasal ve karasal su yaban hayatı, bitki örtüsü, yüzey suyu, yeraltı suyu, gayrimenkul değerleri ve sosyo-çevreye duyarlı topluluklar üzerinde yönetim kararlarının etkilerinin altı çizilmekte. Çalışma da iki tarafın su politika yapıcıları ve endişeli paydaşlar gözetilerek, ABD' ye atık su deşarjında ki potansiyel azalma modelleniyor ve ekosistem servisleri tanımlanıyor, ölçülüyor. Alınan sonuçlar tartışmaları için taraflara sunuluyor. Bu makale, eko- hidrolojik yanıtları ayırt etmenin bir yolu olarak çoklu senaryolar ile bütünleşik havza yönetiminin ekosistem servisleri ile değerlendirmesini sunmakta (Norman ve diğ., 2013).

Bir diğer yayın Brezilya Sao Paulo eyaletinde iki havzada, Jacaré-Guaçu ve Jacaré-Pepira havzalarında yapılan ekosistem servislerinin havza bazında sağladığı faydaları 10 yıllık zaman aralığında değerlendiren 2018' de Brazilian Journal of Biology de Periotto ve Tundisi tarafından yayınlanan çalışmadır. Bu çalışma Brezilya'da ekosistem servisleri ile ilgili çalışma 
İçme Suyu Havzalarının Ekosistem Yaklaşımlı Planlama Paradigmalarının Kapsamı The Scope of Ecosystem Approach Planning Paradigm of Drinking Water Basins

sayısı az olduğu için, bu boşluğu doldurma amacıyla yapılmış özel bir yayındır. Sonuçlar, ekosistem servisleri ile yönetilen alanların diğer alanların önüne çıktığını ve daha sonraki dönemlerde de düzenleme ve bakım hizmetlerinin bu alanlarda azaldığını göstermiştir (Periotto ve Tundisi, 2018).

Son dönem yayınlara birkaç örnek vermek gerekir ise ;

2019 yılında Oreoluwa Ola ve Emmanuel Benjamin'in Forests' ta yayınlanan,"Batı Afrika orman, havza ve sulak alanlarında biyoçeşitlilik ve ekosistem servislerini koruma: Teşviklerin gözden geçirilmesi" konulu çalışmasıdır. Teşvikler üzerine olan bilimsel çalışmalar Sahra altı Afrika'da ki ekosistem servislerine odaklanır iken genelde Doğu ve Güney Afrika üzerine yapılarak Batı Afrika kapsam dışı tutulmaktadır. Bu çalışma koruma konularını derleyerek Batı Afrika'da bu anlamda olan literatür boşluğunu doldurma amacıyla yapılmıştır. Doğal çevreden elde edilen biyoçeşitlilik ve ekosistem servisleri Batı Afrika kırsalında geçimin bel kemiği iken, doğal kaynakların sürdürülemez şekilde kullanımı, çatışmalar, iklim değişikliği ekosistem servislerinin devam etmesini tehdit etmektedir. Bu tehdit çevrenin bütünlüğü korumak için acil intiyaç yaratıyor. Çevre koruma projelerinin etkin bir biçimde tasarlanması ve büyütülmesi için merkezi koruma projelerinin etkinliğinin değerlendirilmesi gereklidir. Çalışma bu yaklaşımla yapılmıştır. (Ola ve Benjamin, 2019).

2019 yılında Forests'te Michael S. Netzer ve diğ., tarafından yayınlanan çalışmalarında Global uzaktan algılama ürünleri ile hidrolojik modellemeyi birleştirerek tropikal orman kayıplarında havza bazlı ekosistem servislerinin etkisini ölçme konusunu ele almışlardır. Aşağı Mekong havzası tarım ve plantasyon için topraklarında ki ormansızlaşma oranı dünyanın yüksek yerlerinden biridir. Bölgenin ekonomik gelişmesi ve kırsalın nüfusu tatlı su kaynaklarına bağlıdır. Balıkçılık ve tarım gibi sektörleri destekleyen su kaynakları taşkın, kuraklık, kaynak kirliliğinin etkileri ile giderek daha savunmasız hale gelmektir. Ormansızlaşmanın hidrolojikekosistem servislerini de içeren ekosistem servisleri üzerindeki etkileri tatlı suyun kullanılabilirliği ve kalitesini kontrol etmektedir. Bu durum peyzaj, sel, kuraklık, toprak erozyonu, kaynak kirliliği üzerinde de etkindir. Bu yayın da aşağı Mekong havzasından 20012013 yılları arasında alınan global ve bölgesel uzaktan algılama verileri sentezlenip, detaylar geliştirilerek toprak kullanım değişimi haritalanıp, bunlar daha sonra ES değişikliklerini haritalayan benzersiz uzamsal veri kümelerini geliştirmek için hidrolojik modelde girdi olarak kullanılmıştır. Sonuç olarak orman kaybı ile yüzey akışı arasında korelasyon fakat orman kaybı ile sediment verimi arasında yukarı doğru bir ilişki bulunmuştur. Bu durum 22 havzanın tamamında sediment artışı, 22 havzanın 17 sinde nehir suyunun azalması ile sonuçlanmıştır. $\mathrm{Bu}$ sonuçlar ayrıca "havza ekosistem hizmet aracı olarak web tabanlı platform" diye adlandırılmıştır (Netzer ve diğ., 2019).

2019 yılında Ecology and Society'da yayınlanan Vallet ve diğ. yayınladığı çalışma ekosistem servislerinde paydaşların rolleri ve güç - eşitlik ilişkisi üzerinedir. Paydaşların rollerini tanımlamak için Peru Marino havzasında 8 ES seti kullanılarak bir çerçeve oluşturulmuştur. 52 havza paydaşının havzaları nasıl yönettikleri ve ES' den nasıl faydalandıkları anlamak için karşılıklı olarak yüz yüze yapılan yarı yapılandırılmış görüşme yöntemi kullanılmıştır. Yerelden, ulusala tüm paydaşların ES yönetimi ile ilgili aralarındaki anlamlı farkı bulmak için istatistik analiz yöntemi (permutasyon) uygulanmıştır. Havzalarda su miktarı, su kalitesi, tarım üretimi çok sayıdaki paydaş tarafından yönetilmekte idi. Aralarındaki fark, paydaşların faydalanma tipinden ve ES yönetiminde yapılan kasıtlı seçimlerden kaynaklanabilir örneğin yerel faydalar için yapılan tercihler gibi. ES leri yöneten ya da faydalanan paydaşlar arasındaki anlamlı fark en fazla yerel ile iş dünyası arasında idi ve halk toplulukları ile STK'lar en çok ES yönetimine katılan paydaşlar idi. ES lerin daha adil yönetimi, daha fazla çeşitlilikte paydaşın karar alma süreçlerine entegre etmesini amaçlamaktadır. Bu amprik araştırma paydaşların rollerini ve güç dağılımını belirleyen faktörleri açıklamaktadır (Vallet ve diğ., 2019). 
Int. J. Environ. Res. Public Health 'de yayınlanan yerel halkın ekosistem hizmetlerine ilişkin algıları: Fenghe nehrinin vaka çalışması konulu çalışma Zhang ve diğ. (2019) tarafından yapılmıştır. Bu yayın için Fenghe havzasında ES ve biyoçeşitlilik konularında sosyal algıyı ölçmek için 386 yerel sakin ile anket çalışması yapılmıştır. ES ve biyoçeşitliliği fiyatlandırmak için hypotethical market metodu kullanılmıştır. Heterojenlik analizinde, bağımsız örnek T- testi, tek yönlü ANOVA, spearman korelasyonu kullanılmıştır. Fenghe nehri havzasın ES' ni geliştirmek için devletin mali kaynaklarına dayalı çok kanallı fon oluşturulması ve kirlilik kontrolü ile ES hakkında farkındalık oluşturulması amacı ile bölge sakinlerine yönelik yönetim modelleri geliştirmiştir. Paydaşların ES algılarını karar almaya entegre etmek, Fenghe nehri havzasında sürdürülebilir kalkınmayı teşvik edebilir sonucuna varılmıştır (Zhang ve diğ., 2019).

\section{Hidrojeolojik Olarak Havza Değerlendirmesi}

Yerkabuğu içindeki suların hareketi, fiziksel ve kimyasal özellikleri, kayaçlar içinde bulunuş şekilleri ve etkileşimi Hidrojeolojinin konusudur. Hidrojeolojik havza değerlendirmesi yapılırken, yeraltısularının jeolojisi, hidrolojisi, hidroliği, hidrodinamiğini incelemek gerekmektedir. Hidrojeoloji çalışmalarında amaç:

- Su kaynakları potansiyelinin değerlendirilmesi,

- Yeraltısuyu kaynaklarının yönetimi ( aşırı kirlenme ve tüketimden koruma)

- Yüzey suyu-yeraltısuyu etkileşiminin ortaya konması

- Yeraltısuyu kirliliği

- Yeraltısuyu geçiş süresinin belirlenmesi (URL-12)

Hidrojeoleojik olarak değerlendirme amacı ile yapılması gerekenler arasında havza da şantiye düzenine geçilerek araştırma kuyuları açılması gelmektedir. Buradan elde edilen verilerden, kuyu hidroliği kullanılarak, akifer parametreleri (permeabilite, etki yarıçapı vs.) belirlenir. Akifer parametreleri araştırma kuyularında belirlenir ve bu bilgiler ışığında susuzlaşmaya yönelik çözümler bulunabilir. Akifer parametrelerini doğru hesaplamak için, araştırma kuyu bölgesinin lokasyon temsil yeteneği yüksek olması önemlidir.

Zamana bağlı düşüm değerlerinin grafiği çizilerek dengeli-dengesiz rejime bakılır. Dengesiz rejimde en çok kullanılan yöntemler:

- Theis Yöntemi (Sabit debi ile pompaj yapıldığında düşümün kuyudan itibaren azalarak ta olsa etkisinin devam etmesi ile akifer hidrolik parametrelerinin belirlenmesi şeklindedir)

- Jacop Yöntemi (yarı logoritmik düşüm-zaman ya da düşüm - uzaklık grafikleri ile parametreler hesaplanır)

Havza da yeraltı suyu akım modeli belirlenirken yağışın olmadığı dönemler hem jeolojik hem de hidrojeolojik ortamlar iyi denetlenip, iyi tanımlanmalıdır (Karagüzel,2020).

\section{Havza Ölçeğinde Hidrolojik Çevrim}

Hidrolojik çevrim, yeryüzünde, yeraltında ve atmosferde suyun varlığı ve hareketidir. Dünyada ki su sürekli hareket halindedir ve faz değiştirmektedir. Su çevrimi milyonlarca yıl devam etmekte olup, yerküre deki hayat buna bağlıdır (URL-11) 


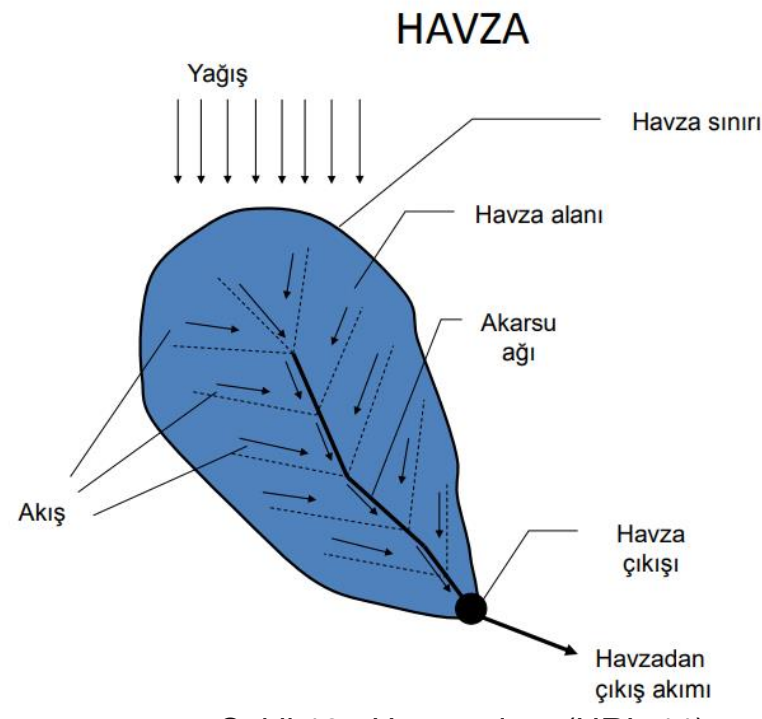

Şekil 13 : Havza alanı (URL-11)

Havza alanında (Şekil 13) hidrolojik çevrim bileşenleri Yağış $(Y)=$ Buharlaşma(B)+Akış(A)+ Sızma(S) şeklinde formüle edilir. Formül içeriğine etki eden bileşenlere bakacak olur isek; Yüzeysel akışa (A) etkiyen faktörler:

- Topoğrafya

- Jeolojik durum

- Meteorolojik durum (yağış şiddeti, süresi, nem, sıcaklık)

- Bitki örtüsü ve insan yapıları

- Akarsu ağı

- Baz akım eğrisi ( yüzeyde akan su ve yeraltı giden ve tekrar ekosistemi besleyen su)

- Yüzey suyu, yeraltı suyu etkileşimi (Birbirlerini besleme durumları)

Buharlaşmaya (B) etkileyen faktörler:

- Sıcaklık, yükseklik ve hava akımı ile doğru orantıı

- Atmosfer basıncı, su derinlik, nem, erimiş tuz oranı ile ters orantıı

Sızmaya (S) etki eden faktörler:

- Zeminin dokusu ve yapısı, permeabilitesi, nemlilik derecesi

- İklim, bitki örtüsü, topoğrafya

- Zeminin kimyasal bileşimi (N, NH4'lu gübrelerin sızmaya etkisi) (Karagüzel,2020).

\section{Bütünleşik Havza Yönetimi}

Bütünleşik havza yönetimi kavramı, 1990 yıllardan itibaren uluslararası kuruluşlar tarafından gündeme taşınmış olup stratejik bir doğal kaynak olan suyun sürdürülebilir kullanımını teşvik ederek su ekosistemlerinin ve bunlara bağlı diğer ekosistemlerin havza bazında korunması, iyileştirilmesi ve olası tahribatların önlenmesini hedeflemektedir (URL-13).

Bütünleşik Havza Yönetimi; su, toprak ve ilgili tüm doğal kaynakların sürdürülebilir bir biçimde yönetimi için uluslararası alanda kabul gören bir yaklaşımdır.

Farklı sektörlerin ve kaynak kullanıcılarının bir arada düşünülmesine, tehdit ve olanakların uzun vadeli değerlendirilmesine, havza içindeki bir alana yapılan müdahalenin yarattığı olumlu ve olumsuz etkilerin izlenilmesine olanak sağlar. 
Karmaşık havza sisteminin; ekolojik dengeyi gözeten, sürdürülebilirlik hedefleri taşıyan, akılcı, gerçekçi, kaliteli bir yönetim ile yönetilmesini hedefler (URL-14)

Bütünleşik havza yönetimi yaklaşımı, Aralık 2000 tarihinde yürürlüğe giren Avrupa Birliği Su Çerçeve Direktifi'nin desteklediği tek yaklaşımdır. Bütünleşik havza yönetimi planlamanın temel ilkesi, su kaynaklarının tüm kullanımlarının ve bunlarının birbirleriyle etkileşimlerinin birlikte değerlendirilmesi, bu yolla su kaynakları kullanımının sosyal, ekonomik ve çevresel amaçlara uygun şekilde planlanmasının garantilendirilmesidir. Bu yaklaşımla farklı sektörler için üretilen politikaların birbiriyle uyumlu olması sağlanabilir. Ancak bu temel ilkenin ötesinde, planlamanın ayrıntısı ile mekan ve zaman boyutları ne kadar kapsamlı olursa, entegre planlamanın su kaynakları korunmasına ve sürdürülebilir kalkınmaya katkısı o derece fazla olur (URL-15).

Su ile ilgili bugüne kadar yapılan çalışmalar, genelde suyun tüketim noktasına ulaştırılması ve verimli kullanımı üzerinedir. Şekil 14 incelendiğinde suyun depolanma haznesi ve sonrasında yapılan uygulamalar üzerine çalışmalar olduğu görülmektedir. Ancak durum, bu çalışmaların yanında suyun üretildiği memba kısmı ile birlikte bütüncül planlama yapılmasını gerektirmektedir. Su üretim havzalarının memba kısmında yanlış arazi kullanımı engellenmeli, kaynağın kirletilmesi önlenmeli, kaynağa zarar verebilecek doğal, insan kaynaklı baskı yaratan durumlar giderilmeli ve ekosistem ile birlikte toprak korunmalıdır. Havza bir bütün olarak ele alınmalı ve planlamalar buna göre yapılmalıdır (Göl ,2008:180).

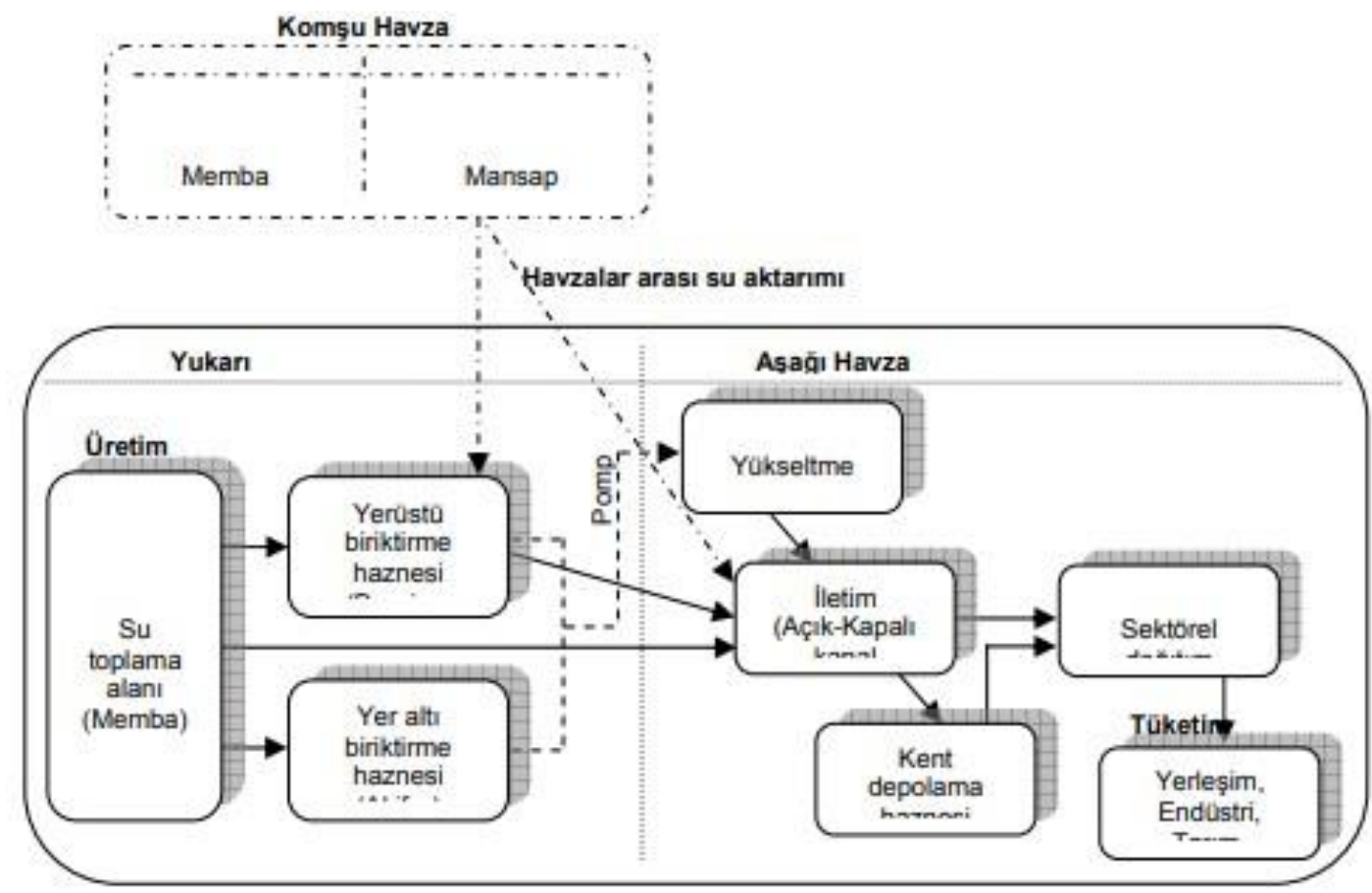

Şekil 14 : Suyun üretiminden tüketimine bulunduğu ortamlar (Göl,2008)

\section{Bütünleşik Havza Yönetiminde Ekosistem Yaklaşımı}

Ekosistemler (ormanlar, sulak alanlar, çayırlar) küresel su döngüsünün merkezindedir. Tüm tatlı su kaynakları sürekli ve sağlıklı ekosistemlere intiyaç duyarlar. Ekosistem yaklaşımı, doğal sistemlerin koruma - kollama dengesi içerisinde yönetilmesini öne çıkaran bir yaklaşımdır.(Url15) Bütünleşik havza yönetimi (BHY) ile ekosistem yaklaşımı arasında benzerlikler bulunmaktadır. Bütünleşik havza yönetimi ile ekosistem yaklaşımının birlikte kullanımında 
- BHY, ekosistem yaklaşımı içerisinde ele alınabilecek alt başlık olarak değerlendirmelidir

- Ekosistem yaklaşımı içerisinde ön plana çıkartılan ekosistem servisleri bu iki yaklaşımın entegre edilmesinde önemli uygulanma aracıdır

Bütünleşik havza yönetimi (BHY) çalışmalarında ekosistem servislerinin öne çıkarıldığı durumlarda havza için fayda ve fırsatlar artmaktadır. Örneğin biyolojik çeşitlilik aracılığı ile elde edilen faydalar, seller ve kuraklık gibi aşırı hidrolojik döngülere karşı sistemin kendini yenileyebilme kapasitesini arttırır. Bu bağlamda iyi yönetilmiş su ve diğer doğal kaynaklar yüksek seviyede ekosistem servisleri sağlayacaktır. Bu yöntem sadece hedeflere ulaşmayı sağlamakla kalmayacak sosyo-ekonomik ve çevresel faydalar da sağlayacaktır (URL-16).

\section{Su Yönetiminde Ekosistem Yaklaşımının Sağladığı Faydalar}

Suyun varlığı ve kalitesi yaşam için sunulan bir ekosistem servisidir yine aşırı hidrolojik olayların (kuraklık, seller gibi) yumuşatılması da ekosistemlerin sağladığı bir servistir. Ekosistemlerin su ihtiyacı, bu ekosistemlerin sağladığı servisleri de içermektedir ve su yönetimi bu yaklaşım ile yapılmalıdır. Ekosistem varlığının ve sağlığının desteklenmesi ile suyun varlığının ve kalitesinin sağlanması arasında bağ bulunmaktadır.

\section{Ekosistemler su tedarikini yönetir}

Bitkinin türü ve miktarı tarafından rüzgar, yağmur ve sıcaklıkların etkisini yumuşatılır. Azalan bitki örtüsü toprağa düşen yağış miktarını etkiler, bu da erozyona neden olur. Ayrıca açık yapılı sağlıklı toprak, suyun toprağa sızmasını kolaylaştırır, yavaş yakışa neden olur.

\section{Ekosistemler su kalitesini düzenler}

Su akışları ile bağlantılı olarak sistemdeki suyun durumu önemli ölçüde değişir. Yüksek yağış durumunda, havzada ki toprak bozulur, akıştaki su toprağın yıkanması ile kirleticiler ve turbudity ile su bulanıklığına neden olabilir. Bu durum su depolama sistemlerinde siltasyon ve su iyileştirme maliyetinin artması ile sonuçlanır. Toprağa nüfuz eden ya da taşkın yatakları ve sulak alanlar üzerinde bulunan su, silt veya kirliliğin depolanmasına ya da uzaklaştırılmasına neden olur. Toprağın içine geçen veya sulak alanlarda ki su fiziksel ve biyolojik süreçler ile temizlenir. Bunun sonucunda da içilebilir kalitede suya ulaşmak için daha az iyileştirme gerekir. Dolayısı ile su toplama havzası, suyun kalitesini etkiler (URL-16).

\section{Ekosistemler aşırı iklim koşullarını ılımlı hale getirir}

Ekosistemler yüksek yağış olaylarında, akışı yavaşlatır ve toprağa sızmayı kolaylaştırır. Ani su baskınları, toprak kaymaları ve çamur akmaları sıklıkla ormansızlaşma ve bozulmuş araziler ile ilişkilidir. Taşkın yatakları ve sulak alanlar nehir boyunca akışta yüksek su barındırır, sızıntı ile dolan yer altı suyu bu akışın etkisini azaltır. Bu durum kuraklık zamanlarında tampon etkisi sağlar. Taşkınlar ve kuraklıklar günümüzde de devam edebilir ancak çalışan ekosistemler ilk savunma hattını oluşturur.

Su sağlayan bazı ekosistemler Tablo 1'de gösterilmiştir. Su yönetiminde doğa temelli çözümler için ekosistemlerin onarımı veya yeni alanlarda benzer şekilde işleyen ekosistem servisleri oluşturmak gerekebilir (URL-16). 
Tablo 1 : Su yönetiminde doğa temelli onarım için uygun ekosistemler (Url-16, UNEP-DHI-NBS' den uyarlanmıştır)

\begin{tabular}{|l|l|l|l|l|}
\hline \multicolumn{1}{|c|}{ Ekosistem } & Su Tedariki & $\begin{array}{c}\text { Aşırı } \\
\text { Koşulları } \\
\text { Ilımlama }\end{array}$ & $\begin{array}{c}\text { Erozyon } \\
\text { Kontrol }\end{array}$ & Su Arıtma \\
\hline Orman ve bitki örtüsü & & & & \\
\hline Toprak & & & & \\
\hline Nehir kenarı örtüsü & & & & \\
\hline Sulak alanlar & & & & \\
\hline Taşkın alanları & & & \\
\hline Bataklıklar, tepeler & & & \\
\hline \multicolumn{2}{|c|}{ (Açık renk :Önemsiz katkı, Koyu renk: Önemli katkı) }
\end{tabular}

\section{Ekosistem Yaklaşımı ve Su Güvenliği Etkileşimi}

Su kaynakları birbiriyle bağlı birçok doğal kaynaktan beslenmekte ve antroponejik kökenli girişimlerin varlığı sebebi ile yapı itibari ile dinamik ve değişken özellikler göstermektedir. Bu sebeplerle su kaynaklarının özel olarak yönetilmesi ve durumlarının her aşaması gerekli izlemelerle takip edilerek potansiyel tehlikelerin su kaynaklarına etki etmeden saptanması ve önlenmesi gerekmekte, ekolojik ve kimyasal durumunun bütüncül bir yaklaşımla havza bazında korunması ve iyileştirilmesi önem arz etmektedir.

Su kaynakları üzerinde baskıların artması sebebiyle önemli seviyede kirlenmeye başlamış ve bu sebeple kötüleşen su kalitesinin çözümüne yönelik yönetim uygulamalarına başlanması gerekmiştir. Teknoloji kaynaklı sınırlar ve ekonomik sebeplerle; su ekosistemlerine ulaşan kirletici yüklerin azaltılmasına yönelik çabalar; geçmişte kirlenmenin tamamen ortadan kaldırılmasını sağlayamamıştır. Bu durum günümüzde de geçerlidir ve gelecekte de geçerli olacaktır. Su kaynaklarının kirlenmesine karşı alınacak tedbirlerin maliyetleri yüksek olduğundan, herhangi bir tedbirin alınmasına karar verilmeden önce, su ekosistemi açısından elde edilecek faydanın ortaya konulması gerekmektedir. Henüz alınmamış bir tedbirin faydasının ortaya konulması ise, ancak öngörü ile mümkündür. Su kaynakları yönetimi; su kalitesi, su miktarı ve sucul ekosistemlerin tamamen birbirine bağlı olduğu büyük oranda bütünleşmiş bir çevreyi kapsamaktadır. Bu nedenle sürdürülebilir bir su yönetiminde su kalitesi, su miktarı ve sucul ekosistemlerin bir arada değerlendirilmesi gerekmektedir.

Su kalitesi suyun fiziksel, kimyasal ve biyolojik özelliklerinin göstergesi olarak tanımlanmaktadır. Su kalitesi standartlarının belirlenmesinde ise suyun kullanım maksadı (içme suyu, tarım, sanayi, enerji vb.) ve su sınıfları (nehir, göl, kıyı-geçiş suları ve yeraltı suları) esas alınmaktadır. Bunun yanında bütün su kaynaklarının bütünsel bir yaklaşımla "iyi duruma ulaşması için daha genel su kalitesi standartları belirlenebilmektedir. Su kalitesi yönetimi açısından risk değerlendirmesi, genel olarak su kaynaklarındaki kirleticilerin insan sağlığı ve sucul ekosistem üzerindeki muhtemel etkilerini ve etkileme riskinin analiz edilerek derecelendirilmesi ve olumsuz etkilerin önlenmesi maksadıyla alınması gereken tedbirleri içermektedir.

Ekosistemlerin sağlığı kavramı, sağlıklı bir ekosistemin sağlam yapılara sahip ve doğal olarak çalışan bir sistem olduğu ilkesine dayanmaktadır. Ekosistemlerin önemli mal ve hizmet sağlama kabiliyetini geri dönüşümsüz biçimde düşürmeden artan su, gıda ve enerji ihtiyacını karşılamak, yirmi birinci yüzyılda toplum için en önemli zorluklardan biridir ve mevcut su güvenliği kavramlarının merkezinde yer almaktadır (URL-17). 


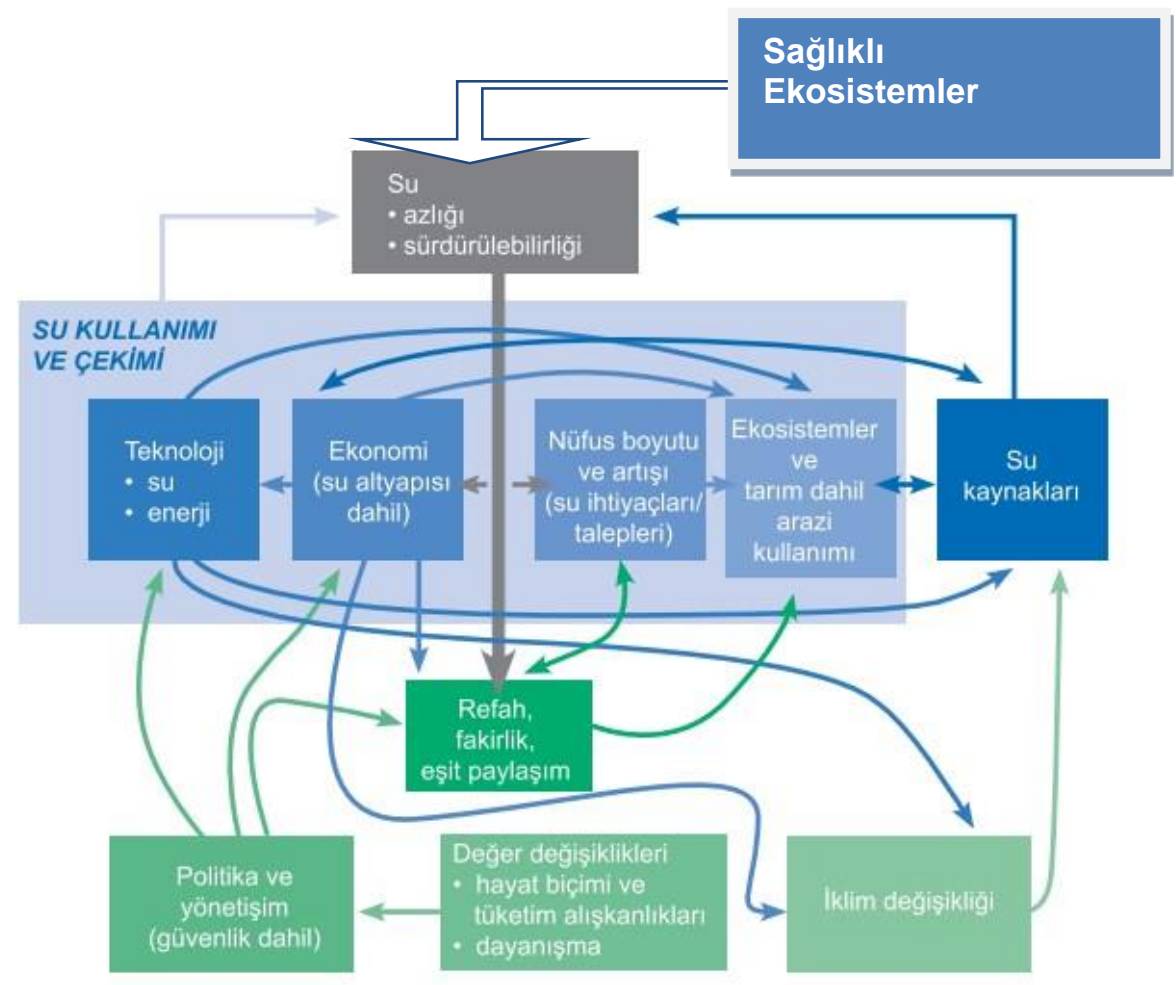

Şekil 15 : Sağlıklı ekosistemlerin su varlığı ve refah ile olan etkileşimi (URL-15' den uyarlanmıştır)

Ekonomik faaliyetleri, arazi kullanım değişiklikleri ve iklim değişikliğini hızlandıran nüfus artışı, küresel su kaynaklarının niteliği ve niceliğine olan baskıyı artırmaktadır. Bu baskılar tüm ekosistemleri ve özellikle tatlı su ekosistemlerini tehdit etmektedir (Şekil 15). Su kalitesinin düşmesi, su kullanımı, ekosistem sağlığı ve işleyişi ve ekosistemlerin desteklediği biyoçeşitliliğe büyük zararlar vermesi nedeniyle küresel bir endişe kaynağı haline gelmiştir. Bu durum dünyanın birçok yerinde, acil eylemlere olan ihtiyaçlara ve sorunların çözülmesi için çözüm taleplerinin artmasına neden olmuştur.

Ekosistem esaslı su kalitesi yönetimi, su kaynakları yönetiminin temel bileşenidir. Ekosistem esaslı su kalitesi yönetimi ile; su kaynaklarının daha fazla tahrip olması engellenecek, iyileştirilmesi sağlanabilecek ve sürdürülebilir su kullanımını gerçekleştirilebilecektir. Aynı zamanda sucul ekosistemler ileri düzeyde korunabilecek ve iyileştirilebilecektir (Selek ve Karaaslan 2019:5). Güvenli ve sürdürülebilir bir yaşam için su kaynakları en değerli doğal varlıklardandır ve sürdürülebilirliği sağlanmadığında yok olabilen yapıdadır.

\section{Bütünleşik Havza Yönetimi'nde Modelleme Araçlarının Seçimi ve Ekosistemlerin Sürdürülebilirliği}

Bütünleşik havza yönetimi için tutarlı bir çerçeve sağlayan Su Çerçeve Direktifi (SÇD) (2000/60/EC), nehir havzası yaklaşımına dayalı su yönetimini benimsemektedir. Nehir havzalarındaki suyun zamansal ve mekânsal dağılımını anlamak, son derece kıymetli su kaynaklarının uygun yönetimini ve korunmasını sağlamak için önemli hale gelmektedir. Bu sebeple, sucul sistemde kısa ve uzun vadeli etkilerin tahmin edilmesinde kullanılan, uygun ölçekte bütün hidrolojik/hidrodinamik/ekolojik süreçleri yansıtan matematiksel modelleri geliştirmek ve uygulamak, başarılı bir nehir havza yönetimi için önemli bir role sahiptir. Su kaynakları yöneticileri, matematiksel modelleri, nehir havzaları üzerindeki su döngüsünde 
ortaya çıkan değişiklikler ile insan etkilerini anlayabilmek ve güvenilir bir şekilde öngörmek için araç olarak uygulamaktadır.

Modeller ile su kalite ve miktarı üzerindeki baskıların azaltılmasına, su kaynaklarının kalite ve miktarının iyileştirilmesine yönelik farklı yönetim politikalarının etkileri ortaya konulabilmekte böylelikle, en uygun su yönetim politikasının belirlenmesine olanak sağlanabilmektedir (Şekil 16). Modeller sayesinde, su kalitesinin geliştirilmesi için yapılması gereken yatırımların kararı, zamanlaması, sınırlı bilgiye sahip olunan parametrelerin su kalitesine olan etkilerinin tahmini gibi konularda hızlı cevap alınmaktadır (URL-18).

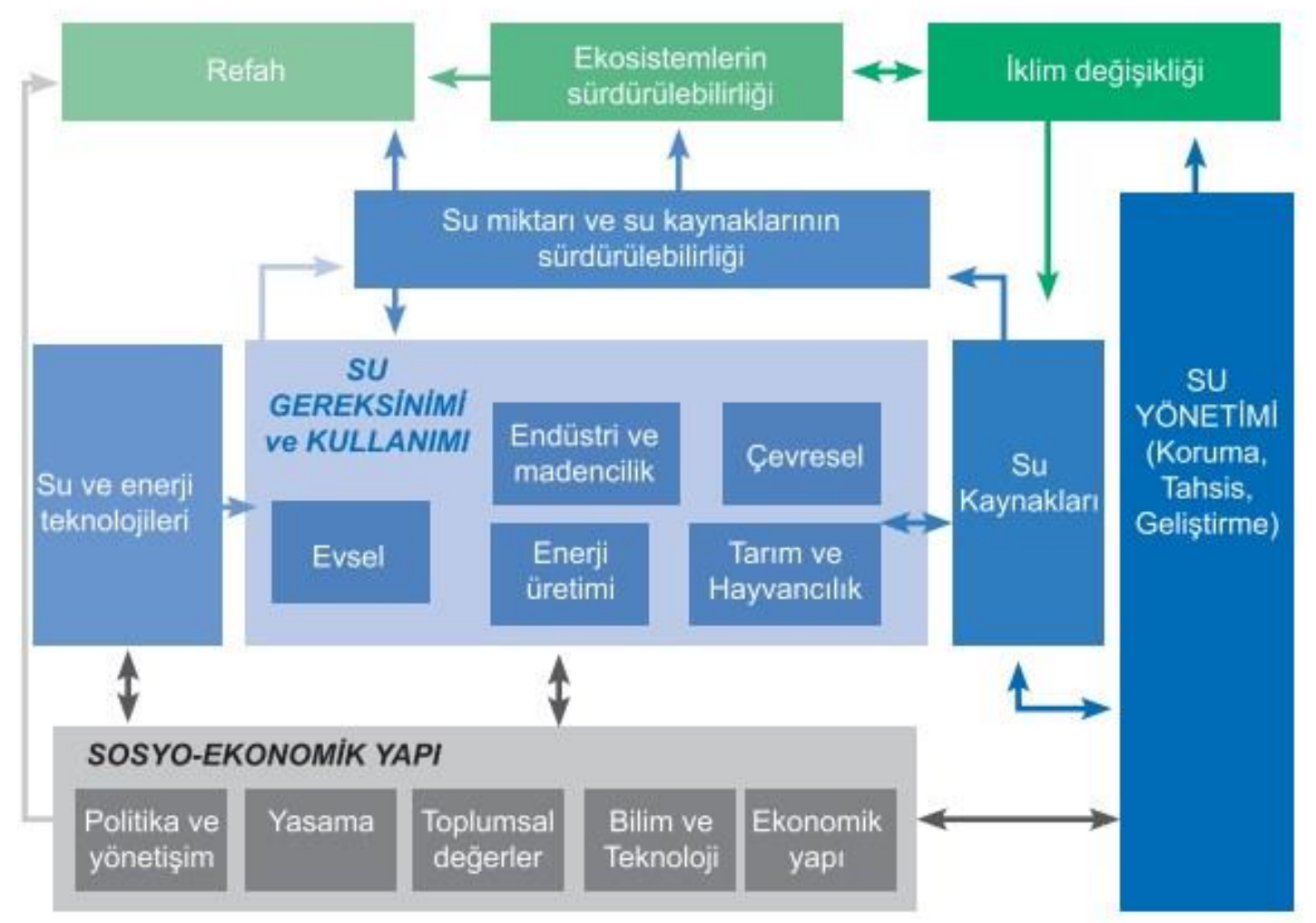

Şekil 16 : Su yönetimi için hazırlanacak bir sistem modelinin ana bileşenleri (Url-15)

Ülkemizde Tarım ve Orman Bakanlığı bünyesinde bulunan SYGM 'de Modelleme Çalışma Grubu tarafından modelleme çalışmaları yapılarak havza ve alt havza ölçekli standart veriler elde edilmektedir (URL-19). Bu birim tarafından kullanılan modellerin bazıları aşağıda verilmektedir (Şekil 17).

- Hidrolojik model: Havzadaki yüzey akışı, su derinliği, yeraltı suyu seviyeleri, su miktarları vb. verileri belirleyen HEC-RAS, Sobek ve WFlow hidrolojik modelleri.

- İklim modeli: Model çıktılarıyla tüm havzalar ölçeğinde sıcaklık, yağış, buharlaşma, akış projeksiyonları oluşturulacak olan modeller: MPI-ESM, HadGEM, GFDL isimli küresel modeller ile RegCM isimli bölgesel model.

- Çevresel kalite modeli : Yerüstü, Kıyı ve Geçiş Suları için Çevresel Kalite Hedeflerin Belirlenmesine Yönelik Metodolojinin Geliştirilmesi için: Yapay sinir ağları, monte karlo simülasyonu ve DELFT 3D modelleri (URL-18). 


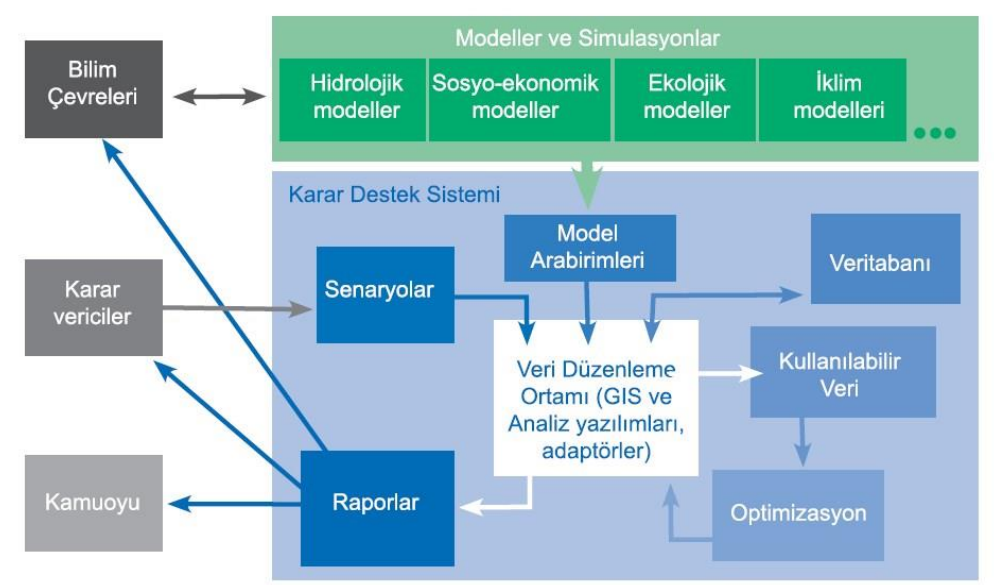

Şekil 17 : Bütünleşik havza yönetimde model ve simulasyoların seçimi (Url-15)

\section{Sonuç ve Öneriler}

Sınırlı doğal kaynaklardan olan içme suyunun etkin ve sürdürülebilir yönetiliyor olması hem günümüz hem gelecek nesiller için hayati önem taşımaktadır. Mevcut kaynakların, su koruma kullanma dengesi paydaşların arz- talep ilişkisi ile birlikte değerlendirilerek paylaşımı, potansiyel su kaynakların ise nerelerde ve hangi kalite ve miktarda bulunduğu bilmek artan nüfus ve talep, değişen iklim koşulları, değişen kullanım alışkanlıkları açısından doğal ekosistemler dikkate alınarak planlama yapma anlamında çok önemlidir. Sürdürülebilir havza yönetimi tüm ekolojik işlevler dikkate alınarak yapılmalıdır.

İçme suyu havzalarını ekosistem yaklaşımlı planlamanın temel koşulu, su sistemlerinin doğal çevre ile etkileşimlerini anlayarak, havzaya heterojen yaklaşıp bir bütün olarak değerlendirip planlama yapmaktır. Bunun yanı sıra içme suyu havzalarının bütünleşik planlanıp yönetilmesinde, ekolojik özellikler ile birlikte bölge halkının sosyo-kültürel yapısı, intiyaçları ve beklentileri de mutlaka dikkate alınmalıdır.

Bölgenin özelliklerine uygun bitki örtüsünün ve toprak yapısının korunması ekolojik dengeyi sağlayarak su üretimini sürdürülebilir kılacaktır. Eğer doğal yapı tahrip olmuş ise, bu durumda su üretimini arttıracak özellikte bitki örtüsünün bölgeye getirilerek alanın rehabilitasyonu üzerine çalışılmalıdır.

İçme suyu havzalarının bütünleşik planlamasında, havza özelliklerinin iyi belirlenmesi esastır. Bundan sonra ki aşama havzaya uygun yönetim modelinin seçilmesi olacağından, havzaya ait parametreler bilimsel şekilde değerlendirilmelidir. İçme suyu havzalarında koruma kullanma dengesi gözetilerek hazırlanan yönetim modelleri, kayıp ve kaçakların azaltılması, su kalitenin arttırılması gözetilerek uygulanmalıdır.

Ülkemizde AB Su Çerçeve Direktifi (SÇD) ve uluslararası sözleşmeler ile uyumlu hazırlanan Su Kanun Taslağı'n da suyun kullanılması, geri kazanılması, tahsisi ve korunmasına ilişkin düzenlemeler yer almaktadır. Bugüne kadar uygulanan geleneksel hidrolojik yönetimde sucul ekosistemlerin korunmasının ön planda olmadığı klasik yaklaşımdan su kaynaklarının havza ölçeğinde bütüncül yönetimi yaklaşımına geçişin taslakta yer alması son derece önemlidir. Ancak bütüncül havza çalışmaların devamı niteliğinde olan Nehir Havza Yönetim Planları (NHYP) henüz tamamlanmamıştır. Su kaynaklarının ve suya bağlı canlıların korunması maksadıyla, katıımı ıir yaklaşımla havzaların tamamında Nehir Havza Yönetim Planlarının (NHYP) hazırlanması gerekmektedir. Söz konusu planlar ile; su kaynaklarının daha fazla tahrip olmasının engellenmesi, daha iyi duruma getirilmesinin sağlanması ve sürdürülebilir su 
kullanımının gerçekleştirilmesi, aynı zamanda suya bağlı ekosistemlerin korunması amaçlanmaktadır. İlave olarak yeraltı sularında kirliliğin azaltılması ve daha fazla kirlenmesinin engellenmesi, taşkın ve kuraklığın etkilerinin azaltılması hedeflenmektedir.

Havza esaslı olan su politikamızı geliştirme ve uygulama konusunda, havzaların yıllar içinde olan arazi kullanım değişiklilerinin tespiti, havza koruma sınırlarının belirlenmesi, havza koruma sınırlarının ekosistem yaklaşımı ile bütünleşmesi, havzada bulunan biyolojik çeşitlilik (tür ve ekosistem olarak) niteliklerinin ortaya konması, hidrojeolojik mekânsal niteliklerin dikkate alınması gerekmektedir.

Tarımsal üretimde suyun verimliliği artırılmalıdır. Türkiye'de suyun yüzde 74'ü sulama maksatlı olarak tarımda kullanılmakta ve bu suyun yüzde 82'si suyun en fazla israf edildiği sulama şekli olan 'salma sulama' şeklinde yapılmaktadır. Tasarruflu sulama sistemlerinden olan damla sulama sisteminin oranı ise yüzde 1. Sulamada kullanılan suyun yüzde 38'i yeraltı sularından karşılanmakta ve bilinçsizce yapılan sulama sonucu yeraltı suları tükenmektedir. Tarımda sulama politikalarının güncellenmesi gerekmektedir.

Havza temelli kuraklık yönetim planları hayata geçirilerek, tüm havzalar için kuraklık yönetim planları tamamlanması gerekmektedir.

Kentlerde su intiyacının azaltılması ve tasarruf edilen suyun tarımda kullanımını sağlayacak tedbirlerin alınması, kentlerde yağmur hasadı uygulamalarının yapılması, park ve bahçelerde su ihtiyacı yüksek bitkiler kullanılmaması, buralarda gri suyun kullanımı yaygınlaştırılması, su tasarrufuna yönelik eğitimler ve uyarıların yapılması gerekmektedir.

\section{Kaynaklar}

Göl Ceyhun, (2008), “Kentsel Su İhtiyacının Karşılanmasında Sürdürülebilir Havza Yönetimi”, TMMOB 2. Su Politikaları Kongresi.

Karagüzel Remzi (2020), İTÜ Jeoleoji Mühendisliği Lisansüstü Programı “ Yeraltı Sularının Değerlendirilmesi" ders notlarından alıntı yapılmıştır.

Kentli Dergisi (Ocak - Şubat - Mart 2018), İçme Suyu Havzaları.

Khan, H.F.,vd., (2017) "A coupled modeling framework for sustainable watershed management in transboundary river basins, Hydrol. Earth Syst. Sci.,", 21, 6275-6288, 2017, https://doi.org/10.5194/hess-21-6275-2017.

Kuru Azem, Tezer Azime, (2020), "İçme suyu havzası koruma sınırlarının belirlenmesine yeni yöntem önerisi: Kırklareli barajı içme suyu havzası örneği”, Journal of the Faculty of Engineering and Architecture of Gazi University 35:1 519-535.

Li, Ping vd., (2016), "Evaluation of Freshwater Provisioning for Different Ecosystem Services in the Upper Mississippi River Basin: Current Status and Drivers" , Water 2016, 8, 288; doi:10.3390/w8070288, (online),www.mdpi.com/journal/water.

Monroe S.James, Wicander Reed, (2005), "Fiziksel Jeoloji - Yeryuvarının Araştırılması", TMMOB Jeoloji Mühendisleri Odası Çeviri Seri No:1

Netzer Michael S., vd., (2019), Combining Global Remote Sensing Products with Hydrological Modeling to Measure the Impact of Tropical Forest Loss on Water-Based 
Ecosystem $\quad$ Services, $\quad h t t p: / / d x . d o i . o r g / 10.3390 / f 10050413, \quad$ (online), http://www.mdpi.com/journal/forests

Norman Laura M. , vd., (2013),"Framing Scenarios of Binational Water Policy with a Tool to Visualize, Quantify and Valuate Changes in Ecosystem Services”, Water 2013, 5, 852-874; doi:10.3390/w5030852, (online), www.mdpi.com/journal/water.

Ola Oreoluwa and Benjamin Emmanuel, (2019), " Preserving Biodiversity and Ecosystem Services in West African Forest, Watersheds, and Wetlands:A Review of Incentives", (online),http://dx.doi.org/10.3390/f10060479, http://www.mdpi.com/journal/forests

Periotto N. A. and Tundisi J. G., (2018)," A characterization of ecosystem services, drivers and values of two watersheds in São Paulo State, Brazil”, Brazilian Journal of Biology, Braz. J. Biol., 2018 , vol. 78, no. 3, pp. 397-407, (online), http://dx.doi.org/10.1590/15196984.166333.

Selek Zeliha, Karaaslan Yakup, (2019) “ Ekosistem Esaslı Su Kalitesi Yönetimi 2019”, (online), https://www.tarimorman.gov.tr/SYGM/Belgeler/Ekosistem\%20Esas1\%C4\%B1\%20Su\%20Kali tesi.pdf

Vallet, A.,vd.,(2019), Linking equity, power, and stakeholders' roles in relation to ecosystem services. Ecology and Society 24(2):14, (online), https://doi.org/10.5751/ES-10904-240214.

Zhang Hongjuan vd., (2019), “Local Residents' Perceptions for Ecosystem Services:A Case Study of Fenghe RiverWatershed", (online), http://dx.doi.org/10.3390/ijerph16193602, http://www.mdpi.com/journal/ijerph.

\section{İnternet kaynakları}

URL-1, Grafik özet uyarlama, 05 Mayıs 2020 tarihinde

https://doi.org/10.1016/j.scitotenv.2019.03.212 internet sitesinden alındı.

URL-2, 04 Şubat 2021 tarihinde http://www.fao.org/zhc/detail-events/en/c/383860 internet sitesinden alındı.

URL-3, UN Water 2019, 04 Şubat 2021 tarihinde

https://unesdoc.unesco.org/ark:/48223/pf0000367306 internet sitesinden alındı.

URL-4, UNESCO WWAP, 04 Şubat 2021 tarihinde http://www.unesco.org/new/en/naturalsciences/environment/water/wwap internet sitesinden alındı.

URL-5, 04 Şubat 2021 tarihinde https://ourworldindata.org/water-access internet sitesinden alındı.

URL-6, 04 Şubat 2021 tarihinde https://www.mgm.gov.tr/genel/hidrometeoroloji.aspx?s=3 internet sitesinden alındı.

URL-7, 04 Şubat 2021 tarihinde https://ourworldindata.org/water-access internet sitesinden alındı.

URL-8, 05 Şubat 2021 tarihinde https://www.tmmmb.org.tr/images/GORUSLERIMIZ/SU_KANUNU_TMMMB_GORUSLERI_K ASIM12.pdf_internet sitesinden alındı. 
URL-9, 05 Şubat 2021 tarihinde Kınacı Cumali, http://cdn.istanbul.edu.tr/statics/subilimleri.istanbul.edu.tr/wpcontent/uploads/2017/09/SU_BILIMLERI_FAK_ACILIS_DERSI_22.09.2017.pdf_internet sitesinden alındı.

URL-10, Ulusal Havza Yönetim Stratejisi (2014-2023), 05 Şubat 2021 tarihinde https://www.tarimorman.gov.tr/SYGM/Belgeler/uhys\%20belgesi\%20(3).pdf internet sitesinden alındı.

URL-11, Hidroloji, 05 Şubat 2021 tarihinde https://aybu.edu.tr/muhendislik/insaat/contents/files/Ders1.pdf_internet sitesinden alındı.

URL-12, 05 Şubat 2021 tarihinde

https://acikders.ankara.edu.tr/pluginfile.php/119617/mod_resource/content/0/hafta1.pdf internet sitesinden alındı.

URL-13, Ulusal Su Planı (2019-2023), 05 Şubat 2021 tarihinde https://www.tarimorman.gov.tr/SYGM/Belgeler/NHYP\%20DEN\%C4\%B0Z/ULUSAL\%20SU\% 20PLANI.pdf_internet sitesinden alındı.

URL-14, 05 Şubat 2021 tarihinde http://www.dsi.gov.tr/dsi-resmi-istatistikler/resmi-istatistikler-2016/2016-y\%C4\%B1/\%C4\%B1-verileri_internet sitesinden alındı.

URL-15, 05 Şubat 2021 tarihinde http://www.skdturkiye.org/files/yayin/Turkiyede-SuyunDurumu-ve-Su-Yonetiminde-Yeni-Yaklasimlar-Raporu.pdf_internet sitesinden alındı.

URL-16, 05 Şubat 2021 tarihinde https://www.unepdhi.org/wpcontent/uploads/sites/2/2020/05/WEB_UNEP-DHI_NBS-PRIMER-2018-2.pdf internet sitesinden alındı.

URL-17, 05 Şubat 2021 tarihinde https://www.hidropolitikakademi.org/tr/article/27006/ekosistem-esasli-su-kalitesi-yonetimi internet sitesinden alındı.

URL-18, 05 Şubat 2021 tarihinde https://www.tarimorman.gov.tr/SYGM/Belgeler/Modelleme\%20Hakk\%C4\%B1nda\%20Strateji $\% 20 v e \% 20$ Yol\%20Haritas\%C4\%B1.pdf internet sitesinden alındı.

URL-19, 05 Şubat 2021 tarihinde https://www.tarimorman.gov.tr/SYGM/Sayfalar/Detay.aspx?Sayfald=32 internet sitesinden alındı.

URL-20, 05 Şubat 2021 tarihinde https://www.tarimorman.gov.tr/SYGM/Belgeler/Su\%20Kalitesi\%20H\%C4\%B0E\%2OHaber\%2 02019/Su\%20Kanunu\%20Tasla\%C4\%9F\%C4\%B1.pdf internet sitesinden alındı.

URL-21, 05 Şubat 2021 tarihinde, http://ctue.mam.tubitak.gov.tr/tr/arastirmaalanlari/butunlesik-havza-yonetimi_internet sitesinden alındı.

URL-22, 05 Şubat 2021 tarihinde, "Su Çerçeve Direktifi Kapsamında Yeraltısuyu Kütlelerinin Belirlenmesinde Tanımlanan Metodoloji ve Türkiye İçin Öneriler", https://www.tarimorman.gov.tr/SYGM/Belgeler/TEZLER/G\%C3\%96K\%C3\%87EN\%20G\%C3 \%96KDEREL\%C4\%B0_UZMANLIK\%20TEZ\%C4\%B0.pdf_internet sitesinden alındı. 